\title{
Two incomplete skeletons of woolly mammoth (Mammuthus primigenius) from the late Pleistocene in the Kirov Region, European Russia
}

\author{
Ekaterina A. Petrova*, Vladimir V. Masutin \& Irina A. Zhuykova
}

\begin{abstract}
This paper presents a description of two unknown incomplete woolly mammoth skeletons discovered in the Kirov Region of the European part of Russia. The first skeleton was found on the Vetluga River, near to the Village of Chernovskoe. The second one was discovered on the Chernyanka River, near to the Village of Shaleevshchina. The Vetluga mammoth showed replacement of the lower molars - $\mathrm{m} 2$ by $\mathrm{m} 3$, and some unfused epiphyses of the bones. Based on qualitative and metric morphological data this skeleton was determined as belonging to an adult male, which probably died at the age of 35-43 years. Its mandible and dentition have a typical morphology, similar to Mammuthus primigenius. The Chernyanka mammoth was a female of estimated age 50-60 years at death. Compared to other European and Siberian skeletons, the Vetluga and Chernyanka mammoths have a body size similar to Mammuthus primigenius, and lived in the late Pleistocene.

How to cite this article: Petrova O.A., Masutin V.V., Zhuykova I.A. 2017. Two incomplete skeletons of woolly mammoth (Mammuthus primigenius) from the late Pleistocene in the Kirov Region, European Russia // Russian J. Theriol. Vol.16. No.2. P.157-175. doi: 10.15298/rusjtheriol.16.2.05

Supplementary materials are available online
\end{abstract}

KEY WORDS: skeleton, Mammuthus primigenius, late Pleistocene, Vetluga River, Chernyanka River, Kirov Region.

Ekaterina A.Petrova [mammut2003@mail.ru ekaterina.petrova@zin.ru], Zoological Institute, Russian Academy of Sciences, Universitetskaya nab. 1, St. Petersburg 199034, Russia; Vladimir V. Masutin [masutka11@yandex.ru], Vyatka State University, Moskovskaya str. 36, Kirov 610000, Russia and Vyatka Paleontological Museum, Spasskaya str. 22, Kirov 610000, Russia; Irina A. Zhuykova [zhuikova@yandex.ru], Vyatka State University, Moskovskaya str. 36, Kirov 610000, Russia

\section{Два неполных скелета мамонта (Mammuthus primigenius) из позднего плейстоцена Кировской области, Европейская Россия}

\author{
Е.А. Петрова*, В.В. Масютин, И.А. Жукова
}

РЕЗЮМЕ. В статье дается описание двух неполных скелетов мамонта из Кировской области, Европейской России. Первый скелет был найден в русле реки Ветлуга, около с. Черновское, второй обнаружен в русле реки Чернянка, возле д. Шалеевщина. В нижней челюсти мамонта с р. Ветлуга идет смена зубов - $\mathrm{m} 2$ на $\mathrm{m} 3$, некоторые эпифизы костей не приросли. На основании морфологических и морфометрических данных установлено, что скелет принадлежит взрослому самцу, возможно погибшему в возрасте 35-43 лет. Его нижняя челюсть и зубы имеют типичную морфологию для Mammuthus primigenius. Мамонт с реки Чернянка, определен, как самка в возрасте 50-60 лет. Ветлужский и Чернянский мамонты показывают сходство в размерах тела с Mammuthus primigenius из Европы и Сибири, время их существования поздний плейстоцен.

КЛЮЧЕВЫЕ СЛОВА: скелет, Mammuthus primigenius, поздний плейстоцен, р. Ветлуга, р. Чернянка, Кировская область.

\footnotetext{
* Corresponding author
} 


\section{Introduction}

The woolly mammoth, Mammuthus primigenius (Blumenbach, 1799), was a widely distributed species during the late Pleistocene of Eurasia (Vereshchagin, 1977, 1979). These animals played an important role in Pleistocene ecosystems. There have been several finds of their complete skeletons in the permafrost of Siberia, but they are rare on the Russian Plain.

The previously discovered skeletons of $M$. primigenius from the Russian Plain (European Russia) are listed chronologically, according to their years of discovery: the Kozlovo mammoth (Kozlovo Village, Perm Region); the Nekhotelovka mammoth (Nekhotelovka Village, Penza Region); the Kamskoe Ust'e mammoth (Kamskoe Ust'e village, Tatarstan); the Tabulda mammoth (Tabulda Village, Bashkortostan, 31360 \pm 250 (Le2153)); the mammoth from Sevsk Site (Sevsk, Bryansk Region, $139507 \pm 70$ (GIN-5778), $13680 \pm 60$ (GIN6209); the Khvadukasy mammoth (Hvadukasy Village, Chuvashiya, $21000 \pm 5000$ (Le-7793à), 17840 \pm 460 (Le7793b)); the Nechereziy mammoth (Nechereziy tract, Republic of Adygea); the mammoth from Kostenki 14 (Kostenki Village, Voronezh Region, 36000-33000); the Bobovo mammoth (Bobovo Village, Saratov Region); the Khoma mammoth (Khoma River, Chuvashiya, 33640 \pm 270 (OxA-17374) (Fig. 1; Averianov, 1992; Garutt, 1992; Ismagilova, 1992; Mashchenko, 1992; Berezin et al., 2001; Khromov et al., 2001; Petrova, 2009; Petrova et al., 2015; Baigusheva et al., 2017).

This paper presents a description of two incomplete skeletons of woolly mammoth discovered in the Kirov Region of the European part of Russia. The first skeleton was found in July 1989 by local resident Igor Kozlov on the Vetluga River, near to Chernovskoe Village (circa N58 $\left.{ }^{\circ} 39^{\prime}, \mathrm{E} 47^{\circ} 24^{\prime}\right)$. There were the several skull fragments, the mandible, the incomplete tusk, and some postcranial parts (spine, ribs, fore- and hindlimb bones), which he found under water in riverbed sediments, about four metres from the water's edge. Igor Kozlov and his helpers also noted that under the water there still remained the difficult to retrieve the second tusk and the greater part of the skull. The size, age and ontogenetic features indicated the excavated bones undoubtedly belonged to a single adult animal.

A second mammoth skeleton was discovered on the Chernyanka River, near Shaleevshchina Village (circa N58 $27^{\prime}$, E48 $67^{\prime}$, altitude ca. $134 \mathrm{~m}$ a.s.1.). The bones were found by local resident Nikolai Patrushev during the summer of 2010, who contacted the Head of the Kotelnich Department of the Vyatka Paleontological Museum about these remains. In the same year and in the period 2011-2012 the excavation was performed by the staff of this Museum. The skeleton was found under water in riverbed sediments, which were composed of dark-grey clay. The bones were scattered across the riverbed (the width of the river is $3 \mathrm{~m}$ ). The bones of the left forelimb and foot were located and further excavated in situ in anatomical order, near to the right bank. On the opposite bank the left tusk and several postcranial parts were excavated (the lumbar vertebra, the right scapula, the right humerus and the pelvis). In addition, several phalanges and fragments of ribs were found in the towing-path, which had been displaced downstream. These bones also belonged to a single adult mammoth.

Institutional abbreviations: GPIM - Institute for Geology and Paleontology of the University of Münster, Münster, Germany; IAM - Ice Age Museum, Moscow, Russia; IEM - Ibresy Ethnographic Museum, Ibresy, Russia; IHMC — Institute for the History of Material Culture Russian Academy of Sciences, St. Petersburg, Russia; IPB — Institute of Paleontology the University of Bonn, Bonn, Germany; KOMK Kirov Regional Museum of Local History, Kirov, Russia; KPM - Kirov/Vyatka Paleontological Museum, Kirov, Russia; LMRC — Ludlow Museum Resource Centre, Shropshire, Great Britain; NMS — Siegsdorf Natural History and Mammoth Museum, Siegsdorf, Germany; NSMLH - Novosibirsk State Museum of Local History, Novosibirsk, Russia; SGM - Stukenberg Geological Museum of the Kazan Federal University, Kazan, Russia; SMNS — Natural History Museum, Stuttgart, Germany; ZIN — Zoological Institute, Russian Academy of Sciences, St. Petersburg, Russia; ZMMU - Zoological Museum of Moscow State University, Moscow, Russia.

\section{Material and methods}

The remains from the Vetluga River are housed at the Kirov Regional Museum of Local History, Kirov City, Russia, with collection number: KOMK 13475/1$13475 / 10,13475 / 12,13475 / 28,14375 / 11,14375 / 13-$ $14375 / 27,31180 / 1-31180 / 6,31180 / 8-31180 / 13$. The remains from the Chernyanka River are housed at the Vyatka Paleontological Museum, also Kirov City, with collection numbers: KPM 337/1-337/20, 337/22-337/ $26,337 / 28-337 / 34$. A full listing of identifiable material is provided in Supplementary Material (S1).

Molar teeth were measured according to Garutt and Foronova (1976). Lamellar frequencies and enamel thickness on lower molars were taken at the occlusal surface, averaged between buccal and lingual sides. Enamel thickness was calculated as average of five to ten measurements taken over the entire length of the occlusal surface. The limb bone measurements are taken according to Von den Driesch (1976), Averianov (1992, 1994), and Garutt (1992). Most comparative measurements are taken from the references, except the Achchygaj-Allaiha Locality and the Khatanga one, where the measurements of the skeletons have been taken by the authors. Measurements were taken with the caliper, and are quoted in millimeters. The morphological features of woolly mammoth and Asian elephant were examined by the authors from the Collections of the Zoological Institute of Russian Academy of Sciences, the Zoological Museum of the Moscow State 


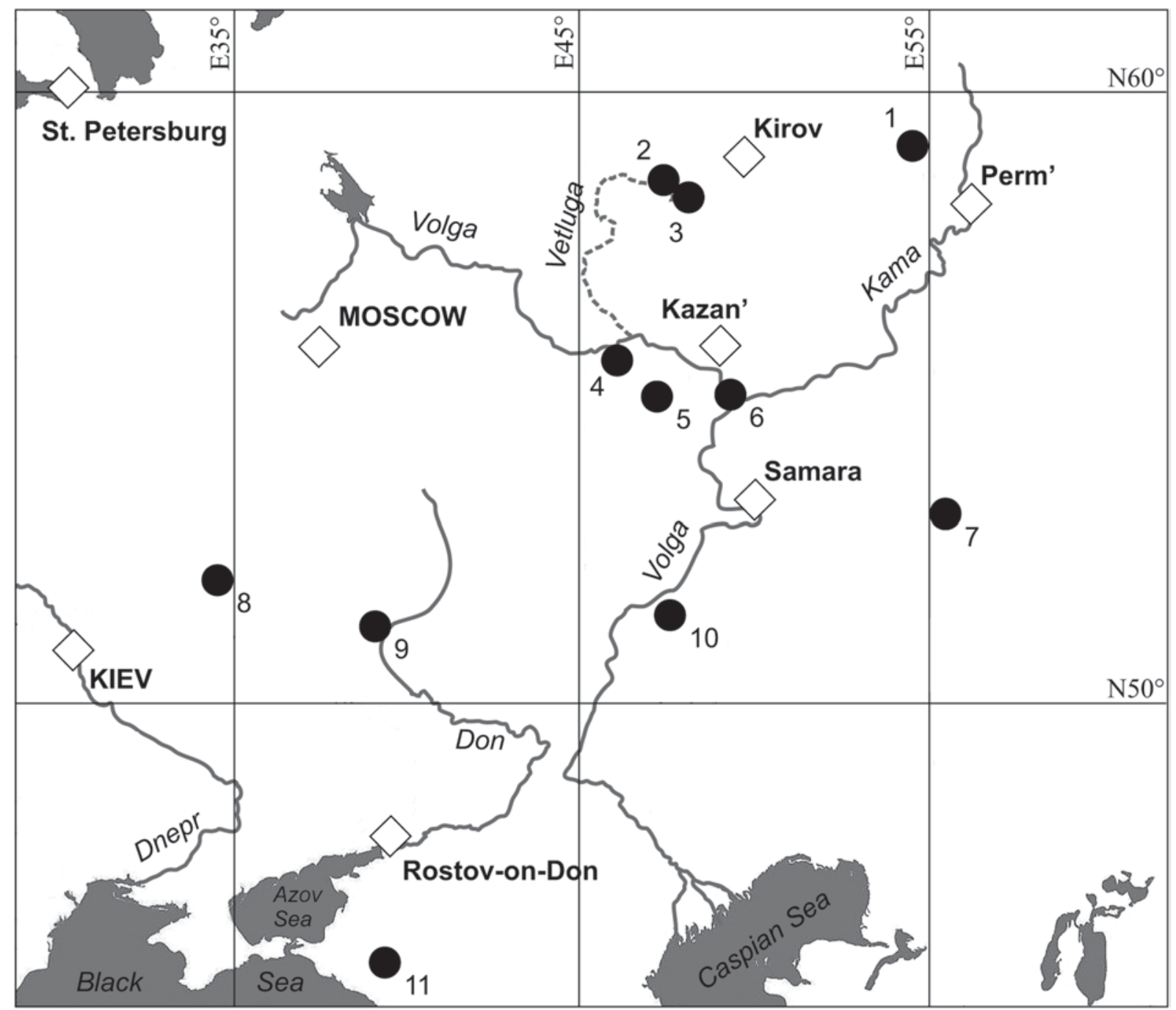

Fig. 1. Map of localities of Mammuthus primigenius skeletons from Russian Plain. 1 - Kozlovo Village, Perm Region; 2 Vetluga River, Kirov Region; 3 - Chernyanka River, Kirov Region; 4 - Hvadukasy Village, Chuvashiya; 5 - Khoma River, Chuvashiya; 6 - Kamskoe Ust'e Village, Tatarstan; 7 - Tabulda Village, Bashkortostan; 8 - Sevsk site, Bryansk Region; 9 - Kostenki Village, Voronezh Region; 10 - Bobovo Village, Saratov Region; 11 - Nechereziy tract, Republic of Adygea (according to Averianov, 1992; Garutt, 1992; Ismagilova, 1992; Mashchenko, 1992; Berezin et al., 2001; Khromov et al., 2001; Petrova, 2009; Petrova et al., 2015; Baigusheva et al., 2017; and original data).

University, the Stukenberg Geological Museum of the Kazan Federal University, the Novosibirsk State Museum of Local History. For the description of the mammoth osteology was taken terminology follow Evans (1993). For the comparisons, we used skeletons of the M. primigenius from known localities (see Table 1).

The upper molars are indicated by upper case, M; the lower ones by lower case, $\mathrm{m}$. The metacarpals are indicated by Mc.

Measurements. HS — height along the spine; GLP greatest length of the processus articularis; SLC smallest length of the collum scapula; LG - length of the glenoid cavity; BG - breadth of the glenoid cavity; $\mathrm{GL}$ - greatest length; $\mathrm{Bp}$ - breadth of the proximal end; Dp - depth of the proximal end; Bd — breadth of the distal end; Dd — depth of the distal end; SD - breadth of the diaphysis in medium part; BT — breadth of the trochlea.

Measurements of each analyzed remain and known mammoth specimens are listed in Supplementary Material (S2).

\section{Description and Comparison}

\section{Vetluga mammoth}

Skull. - The fragment of parietal bone KOMK13475/12, the fragment of zygomatic process of maxilla KOMK 13475/10, and the fragment of premaxilla KOMK 13475/10 are all that remain of the skull.

Mandible. - The mandible KOMK 31180/1 is nearly complete, and only bits of the right and left parts of 


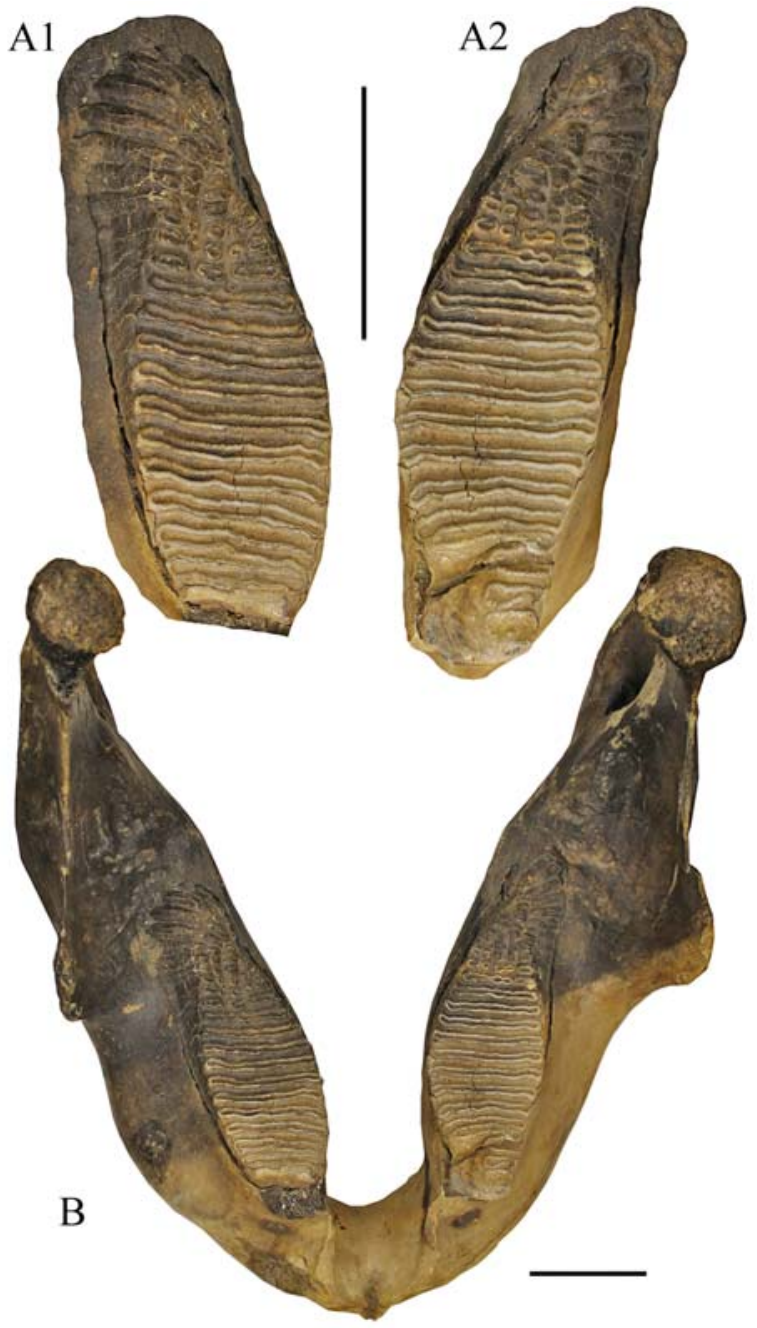

Fig. 2. M. primigenius, Vetluga River, Chernovskoe Village, Kirov Region, European Russia. A - lower molars KOMK 31180/1, occlusal view (A1 - right m3; A2 - left m2-m3); B - mandible KOMK 31180/1, occlusal view. Scale bar = $10 \mathrm{~cm}$.

the coronoid processes and medial edges of the right and left condyloid processes are broken away (Fig. 2B). The symphysis is very massive and strongly protruding. The base of the mental process is preserved and indicates that it was developed. The mandible ramus is higher. The index of the height of the horizontal branch is 1.05. They form an approximate right-angle with the dentary. The masseteric fossa is wide but rather shallow. The mental foramina are strongly developed. The mandibular foramen is of oval form and large size. The right half of the mandible is slightly higher than the left; perhaps it is associated with a heavy load on the left half. The left half of the mandible contains the second (m2) and the third (m3) molars; in the right half only the third (m3) molar is present, because the second (m2) molar was worn out. This sample is large and similar in size with adult woolly mammoth males from Siberia (Table 2).

Tusk. - The proximal end (alveolar part) and the middle part of the tusk KOMK $13475 / 9$ are preserved, while the distal portion and the tip are destroyed (Fig. $3)$. In cross section, the tusk is sub-circular, with a maximum diameter of $160 \mathrm{~mm}$ and a minimum of 150 $\mathrm{mm}$ at its base (alveolar part). The tusk fragment is $1560 \mathrm{~mm}$ long according to the greater curvature and $1200 \mathrm{~mm}$ by the lesser curvature. Although it is incomplete, it the curvature is noticeable.

Lower dentition. - The left second molar (m2) has a small occlusal surface and it is totally worn. It consists of 2.5 plates (in the labial side) that are worn down to the roots. The left third (m3) molar consists of anterior

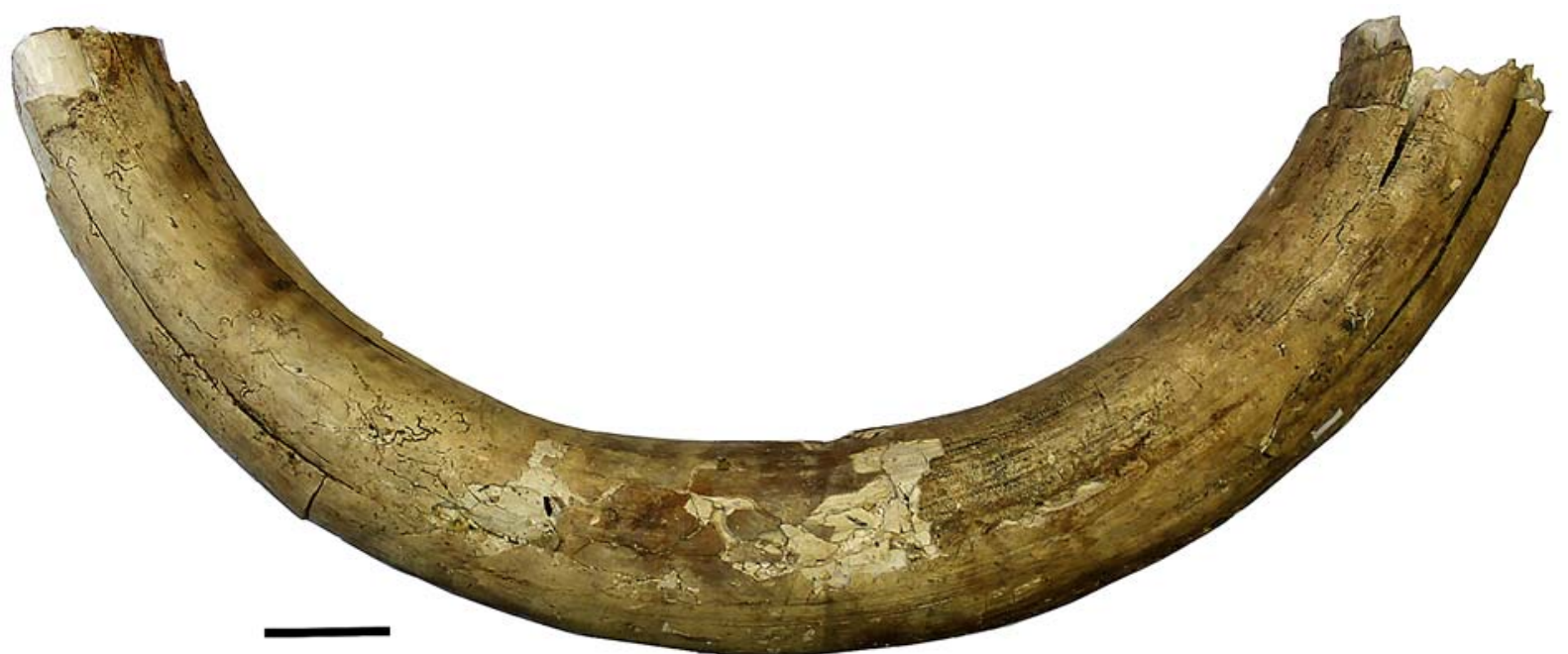

Fig. 3. M. primigenius, Vetluga River, Chernovskoe Village, Kirov Region, European Russia. Tusk KOMK 13475/9. Scale bar $=10 \mathrm{~cm}$. 


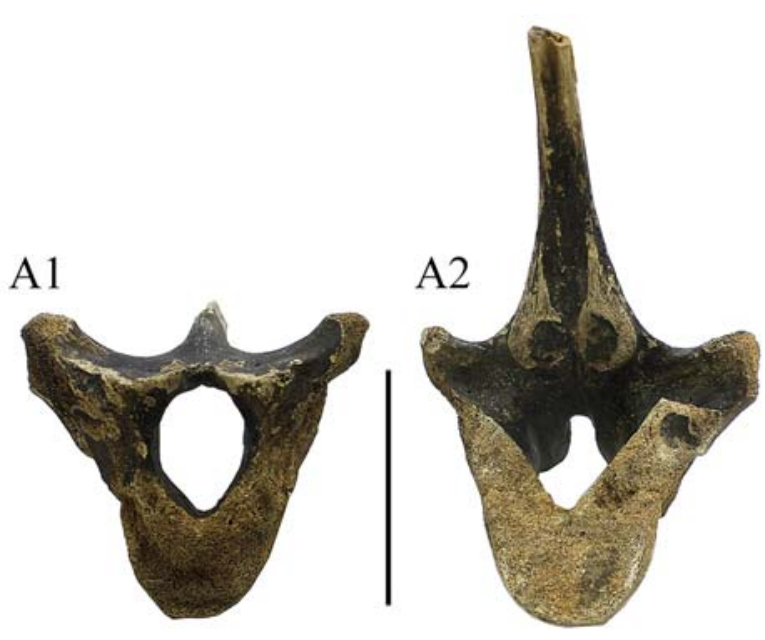

Fig. 4. M. primigenius, Vetluga River, Chernovskoe Village, Kirov Region, European Russia. A - thoracic vertebra KOMK 31180/11 (A1 - cranial view; A2 - caudal view). Scale bar $=10 \mathrm{~cm}$

talonid and 20 plates and posterior talonid inside the alveolus at the posterior part of the body of the mandible. Thirteen plates and the anterior talonid are worn (the 11-13th plates are hardly worn), forming an occlusal surface that is $220 \mathrm{~mm}$ long and $89 \mathrm{~mm}$ wide. The right third (m3) molar is similar to the left, but it consists of anterior talonid and 19 plates and posterior talonid inside the alveolus at the posterior part of the body of the mandible (Fig. 2A1, A2; Table 3). Sixteen plates and the anterior talonid were in use (plates 11-16 are hardly worn). Its occlusal surface is $235 \mathrm{~mm}$ long and its width $88 \mathrm{~mm}$. The frequency of the plates of 10 $\mathrm{cm}$ is 9 ones. The enamel is smooth, without wrinkles and the thickness of the enamel is $2 \mathrm{~mm}$.

Thoracic vertebra. - In two fragments, KOMK $31180 / 10,31180 / 12$, spinous processes and their transverse pairs are present. Another two vertebrae KOMK $31180 / 11,31180 / 13$ consist of a partially destroyed spinous process and the body of the vertebra (Fig. 4A1, A2; Table 4). These samples have bodies with unfused cranial and caudal epiphyses. The epiphyses are lost. It is not possible to determine their anatomical position, because they are incomplete.

Sacrum. - Only two bodies of the first and the second sacrum vertebra KOMK 14375/11 are preserved (Fig. 5C1, C2). The spinous and transverse processes are destroyed. The cranial and caudal epiphyses of the bodies are completely unfused. Therefore, the bodies are unfused to each other.

Ribs. - Due to their incomplete preservation, the ribs were not identified anatomically; their relative position could only be characterised as posterior. The heads are unfused and lost.

Scapula. - The right scapula KOMK $13475 / 7$ is incompletely preserved (Fig. 5A; S2). The middle part of the spine, portions of the supraspinous fossa and the infraspinous fossa and dorsal border are broken. The spine is almost straight, presenting a weak concavity cranially. The apophysis is unfused; the preserved margin of the dorsal border is indicated. It's height along the spine is quite similar to the Rottweil mammoth, exceeding that of the Chernyanka, Oesh, and Kastykhta$\mathrm{kh}$ mammoths, but smaller than that of the Lyakhov, Berezovka, Kozlowo, Taymyr, Lena and West European mammoths (Fig. 6A; S2). The dimensions of the glenoid cavity are quite similar to those of mammoth specimens from the Chernyanka, Kamskoe Ust'e, Lyakhov, Berezovka, Kozlowo, Taymyr, Mohov, and Rottweil specimens; they exceed those of the Oesh and Kastykhtakh mammoths and are smaller than Lena and West European mammoths (S2).

Humerus. - The right humerus KOMK 13475/1 is complete (Fig. 5D; S2). The broad deltoid tuberosity extends from the mid-shaft to the teres tuberosity. The head is elongated craniocaudally and exceeds the greater tubercle proximally. The distal epiphysis is well fused and the suture is fully obliterated. The head is unfused and with an open epiphyseal suture. The humerus is, in all measurements, distinctly larger than the Oesh, Kastykhtakh, Sanga-Yurakh and Rottweil Mammuthus specimens. It is similar with humerus of the mammoths of Berezovka, Kozlowo, and Taymyr. This bone of the Vetluga mammoth is smallest of the West European and some larger Siberian (Khatanga, Achchyigyiy-Allaiha, Lena and Mokhov) mammoth skeletons (Fig. 6B; S2).

Ulna. - The right KOMK 13475/2 and left KOMK 13475/5 ulnae are completely preserved (Fig. 5F1, F2; S2). Only the right ulna has no distal epiphysis, because it was unfused and lost. Both epiphyses of olecranon are fused, but with an open epiphyseal suture. The distal epiphysis of the left ulna, while firmly attached to the shaft, is not completely fused, exhibiting a deep cleft caudally, along the fusing line. All measurements of the ulna in the Vetluga mammoth are larger than those for the Oesh, Kastykhtakh, Sanga-Yurakh, Chernyanka and Rottweil mammoths. It is similar in size to the humerus of the mammoths of Kozlowo and Taymyr. The ulna is small compared with the West European mammoths and large males of the Siberian (Khatanga, Achchyigyiy-Allaiha, Lena and Mokhov) mammoth skeletons (Fig. 6C; S2).

Pisiform. - The left KOMK $31180 / 6$ pisiform is complete (Fig. 5K1, K2; S2). The distal epiphysis is completely fused. The cuneiform facet is rectangularshaped and does not extend the length of the bone. This facet is different in the woolly mammoth of Chernyan$\mathrm{ka}$, Kostenki and Rottweil. Obviously, this feature is rather variable. The greatest height of the pisiform in the Vetluga mammoth is similar with that of the Kamskoe Ust'e specimen, but in this measurement it exceeds that of the Kastykhtakh, Chernyanka, Kostenki and Rottweil mammoths (see S2). Accordingly, the pisiform of the Vetluga mammoth is somewhat shorter than that of the mammoths of Ahlen and Borna (S2). 


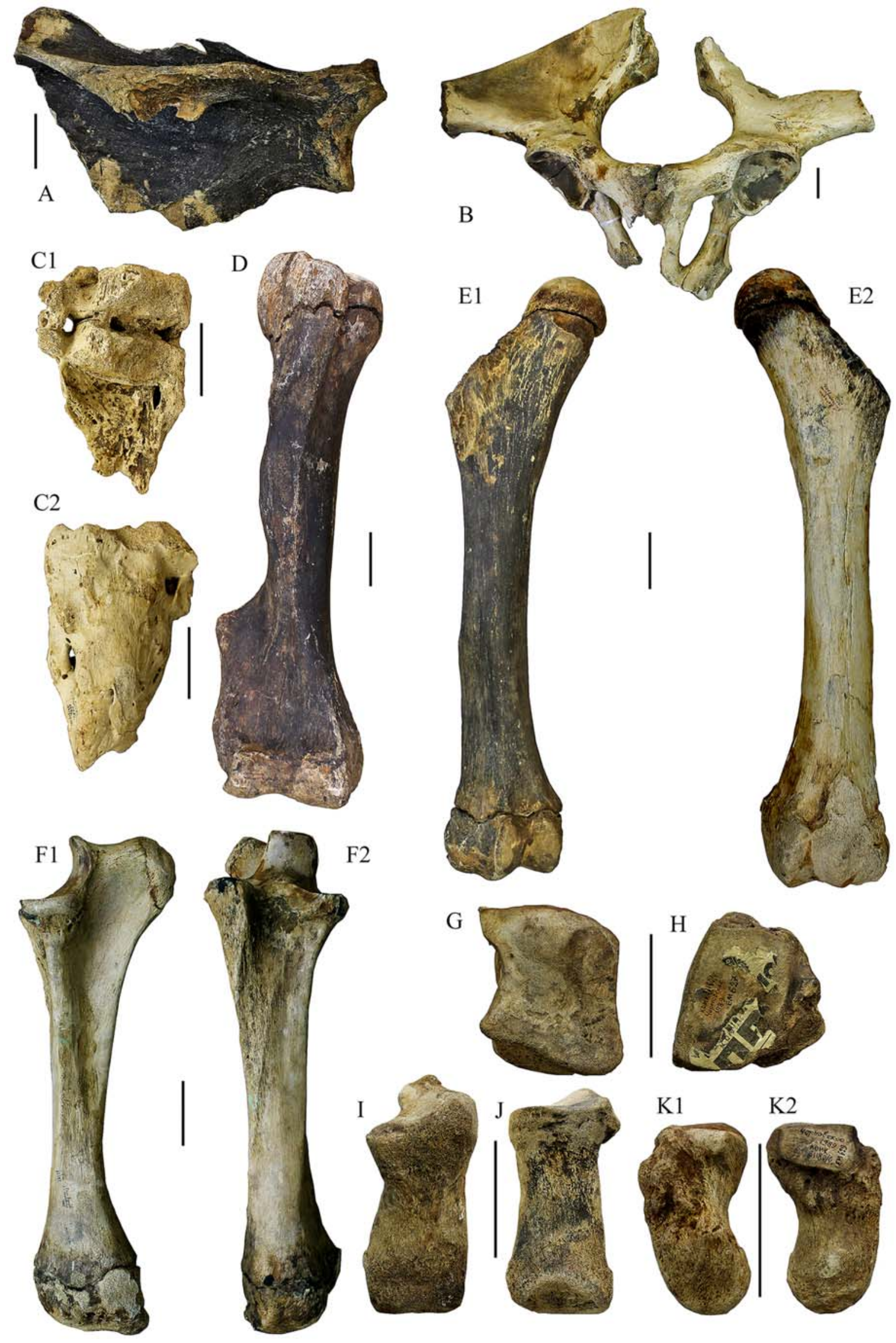


Capitate. - The left capitate KOMK $31180 / 8$ is completely preserved (Fig. 5G; S2). The proximal surface is nearly trapezoidal; only its medial border is slightly concave. There are many foramina of blood vessels on the cranial surface of the bone. The capitate dimensions are similar with all comparable specimens (see S2).

Hamatum. - The left hamate KOMK 31180/4 has an ordinary structure (Fig. $5 \mathrm{H}$; S2). All surfaces of the hamatum are incompletely ossified. There are many foramina of blood vessels on the cranial surface of the bone. The greatest width and depth of the hamatum in the Vetluga mammoth exceeds those dimensions in the Kostenki, Kamskoe Ust'e, Chernyanka and Berezovka mammoths, but it is smaller than the hamatum in the Ahlen and Borna mammoths (S2).

Metacarpals. - Only the left second KOMK 31180/ 5 and left third KOMK 31180/9 metacarpals were found (Fig. 5I, J; S2). The second and the third metacarpals are elongated, robust, dorso-palmarly flattened bones, with wide proximal articular facets for the distal carpal row and a distal trochlea for the articulation of the proximal phalanges. Both bones have fused distal epiphyses. The metacarpals of the Vetluga mammoth are larger than those in the mammoths of Kamskoe Ust'e, Kastykhtakh, Berezovka, and Chernyanka, but smaller than those in the Borna mammoth (S2).

Pelvis. - The pelvis KOMK 13475/6, 13475/8 is incomplete (Fig. 5B; S2). Parts of the right wing of the ilium, the medial and lateral parts of right ischium bone, the left and right parts of the ischiatic arch, and the left crest of ilium are destroyed. The apophysis of the wing of the ilium and the pubic part of the symphysis pelvis are unfused. The acetabulum is large.

Femur. - The right KOMK 13475/3, 31180/3 and left 13475/4, $31180 / 2$ femurs are nearly complete (Fig. $5 \mathrm{E} 1, \mathrm{E} 2 ; \mathrm{S} 2)$. A small portion of the cranial surface of the left lateral condyle is missing. Both apophyses of the trochanter are unfused and lost. The heads are nearly hemispherical and unfused. The neck is short. The right distal epiphysis is unfused and with an open epiphyseal suture; in contrast the left distal epiphysis is completely fused and the suture is fully obliterated (Fig. 4E1, E2). The shaft is compressed cranio-caudally, becoming more oval in cross-section only in the most distal part. The femur of the Vetluga mammoth is smaller that of West European and some large Siberian (Khatanga, Achchyigyiy-Allaiha, Lena and Mokhov) mammoth skeletons (Fig. 6D; S2). It exceeds the size of the femur of the mammoths of Oesh, Kastykhtakh, Sanga-Yurakh and Rottweil. The measurements of the femur are similar with those of the Lyakhov, Kamskoe Ust'e, Berezovka, Kozlowo and Taymyr mammoths (Fig. 6D; S2).

\section{Chernyanka mammoth}

Tusk. - The left tusk KPM 337/32 is completely preserved. It is quite thin, and has a diameter at the base of $57 \times 46 \mathrm{~mm}$ (Fig. 7B1, B2). The total length of the tusk measuring the greater curvature is $1128 \mathrm{~mm}$, and measuring the smaller curvature, $970 \mathrm{~mm}$. It is slightly involute. There is wear on the front surface of the end of the tusk.

Lumbar vertebra. - The lumbar vertebra KPM $337 / 19$ is nearly complete (Fig. 7G1, G2; S2). The distal part of the spinous process and portion of the right cranial articular process are partly broken off. Both transverse processes are destroyed. The epiphyses of the cranial and caudal articular surfaces are completely fused.

Ribs. - In the nearly complete first left KPM 337/ 8 and right KPM 337/33 ribs, only small parts of the distal ends are broken off (Fig. 7F1, F2). The lengths by the greater curvature are $490 \mathrm{~mm}$ in KPM 337/8 and $500 \mathrm{~mm}$ in KPM 337/33, by the smaller curvature, 440 and $430 \mathrm{~mm}$, respectively. The heads are fused. Additionally, six fragments of the ribs are preserved. Specimen KPM 337/11 is a head; the other specimens KPM $337 / 22-25,337 / 34$ are bodies of the ribs.

Scapula. - The right scapula KPM 337/30 is incomplete (Fig. 7A1, A2). The glenoid cavity, the tuber scapulae and the portion along the spine is preserved. The supraspinous fossa is completely missing, and the infraspinous fossa is missing to a great extent. In measurements of the scapula head, scapula cervix, and glenoid cavity it exceeds the Oesh and Kastykhtakh mammoths, but is similar to the mammoths from Kamskoe Ust'e, Kozlovo, Berezovka, and Taymyr, and smaller than the Lena and Mohov mammoths (Fig. 6A; S2).

Humerus. - The distal end of the right humerus KPM 337/26 is broken away (Fig. 7C1, C2; S2). The lateral surface of the head is somewhat rough. The caudal surface of the greater tubercle and the crest of greater tubercle are much rougher. The proximal epiphysis is completely fused.

Ulna and radius. - The left ulna and left radius KPM 337/31 are perfectly preserved (Fig. 7E). They are fused with each other in the radial notch, for two thirds of the total length of the diaphysis, and at the distal end. In spite of this, there is distal interosseous space between the ulna and radius. The apophysis of olecranon and the distal epiphyses of these bones are

Fig. 5. M. primigenius, Vetluga River, Chernovskoe Village, Kirov Region, European Russia. A — right scapula KOMK 13475/7, lateral view; B - pelvis KOMK 13475/6,8, ventral view; C - sacrum KOMK 14375/11 (1 - ventral view; 2 dorsal view); D - right humerus KOMK 13475/1, cranial view; E - femur, cranial view (E1 - right KOMK 13475/3, 31180/3; E2 - left KOMK 13475/4, 31180/2); F - left ulna KOMK 13475/5 (F1 - medial view; F2 - cranial view); G left capitate KOMK 31180/8, proximal view; H - left hamate KOMK 31180/4, proximal view; I - left Mc2 KOMK 31180/ 5, cranial view; J - left Mc3 KOMK 31180/9, cranial view; K — left pisiform KOMK 31180/6 (K1 — lateral view; K2 medial view). Scale bar $=10 \mathrm{~cm}$. 

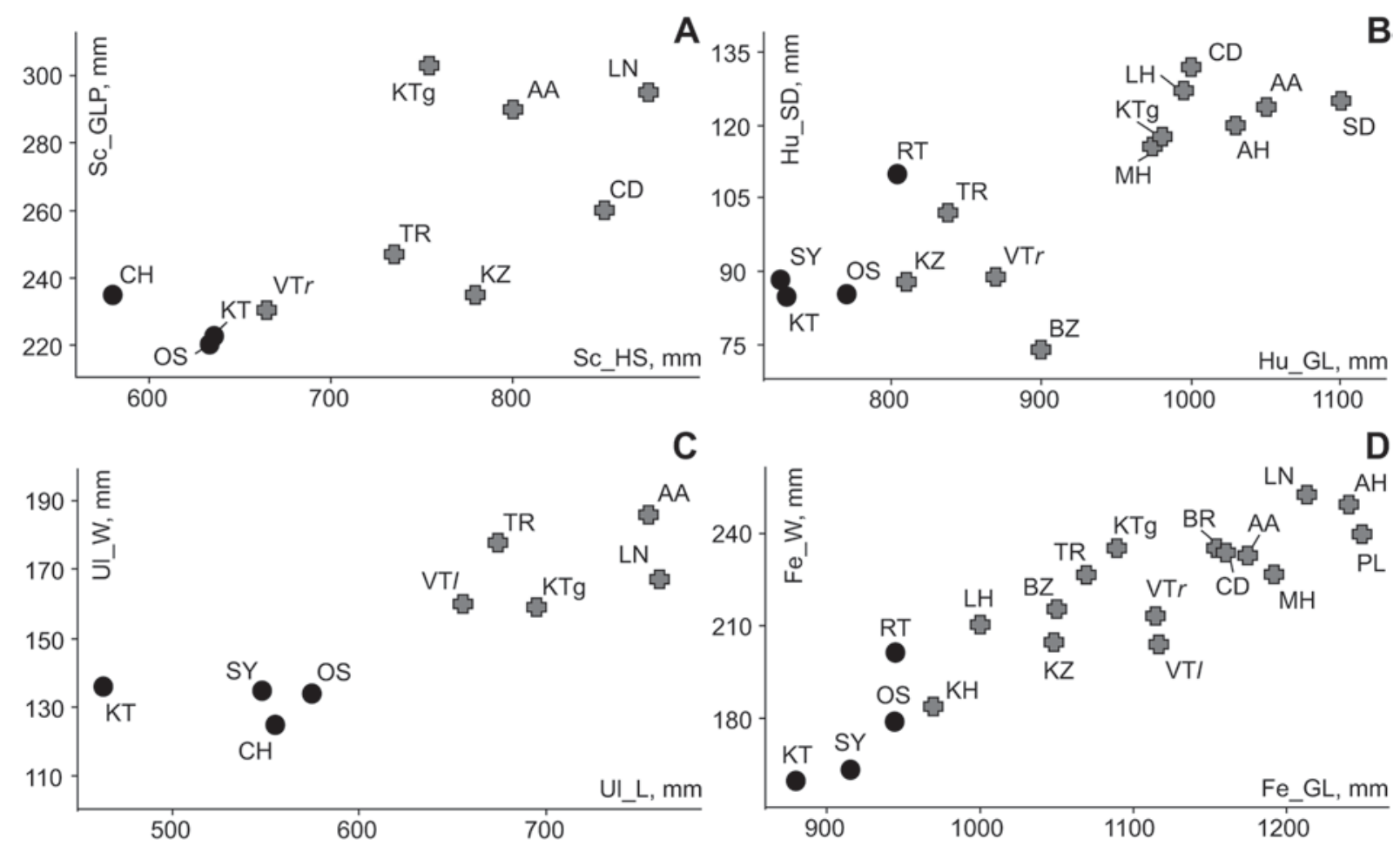

Fig. 6. Ratio diagram of limb bone lengths and widths in Eurasian female and male M. primigenius skeletons. A. The ratio of scapula height along the spine (HS) vs greatest length of the processus articularis (GLP); B. The ratio of humerus greatest length (GL) vs breadth of the diaphysis in medium part (SD); C. The ratio of ulna length from the anterior edge of semilunar incisure to distal end (L) vs the width of distal end at the level of epiphyseal suture (W); D. The ratio of femur maximal length from the top of a head to lateral end (GL) vs the maximal width between external edges of articular condyles (W). Designation: $\mathrm{Sc}$ - scapula; Hu — humerus; Ul — ulna; Fe — femur. Circles display females, crosses display males. Localities: AA — Achchyigyiy-Allaiha; AH — Ahlen; BR — Borna; BZ - Berezovka; CD — Condover; CH — Chernyanka; KH — Khoma; KT - Kastykhtakh; KTg - Khatanga; KZ - Kozlowo; LH - Lyakhov; LN — Lena; MH — Mohov; PL — Polch; OS Oesh; RT — Rottweil; SD — Siegsdorf; SY — Sanga-Yuryakh; TR — Taymyr; VT $r$ - Vetluga, right bones; VT $l$ - Vetluga, left bones.

completely fused. The ulna and the radius of the Chernyanka mammoth are in all measurements distinctly smaller than those of the Kamskoe Ust'e, Lyakhov, Vetluga, Berezovka, Kozlowo, Achchyigyiy-Allaih, Khatanga, Taymyr, Mohov, Lena and some West European mammoths, but similar in size with those of the Oesh, Kastykhtakh and Rottweil mammoths (Fig. 6C; S2).

Scaphoideum. - In the medial view, the left scaphoideum KPM 337/7 is of trapezoidal form (Fig. 7E). The palmar surface is covered with a tuberosity and greater numbers of foramina of blood vessels. The radial facet has a semi-circular shape, slightly concave and slanted dorsally. The trapezoid facet extends proximo-laterally over roughly one third of the total length of the bone. The greatest height of the scaphoideum in the Chernyanka mammoth is smaller than that in the mammoth from Kamskoe Ust'e (M2-M3), but in width and depth it is similar with this mammoth (S2).

Lunatum. - The lunatum KPM 337/3 is triangular shaped in outline, and overall is similar in shape to other known specimens of same ontogenetic age (Fig. 7E). The proximal, distal, medial and lateral facets of this bone have a structure close to that of $M$. primigenius specimens from Kamskoe Ust'e, Berezovka, and Rottweil. The Chernyanka specimen is in all measurements of the lunatum similar with the samples from Kamskoe Ust'e and Rottweil, but smaller than in the mammoths of Borna and Polh (S2).

Triquetrum. - The triquetrum KPM 337/2 is also of triangular shape, with a long latero-palmar extension (Fig. 7E). On the dorsal and palmar surfaces of this bone there are tuberosities and greater numbers of fo-

Fig. 7. M. primigenius, Chernyanka River, Kirov Region, European Russia. A - right scapula KPM $337 / 30$ (A1 - lateral view; A2 - caudal view); B - left tusk KPM 337/32 (B1 - dorsal view; B2 - lateral view); C - right humerus KPM 337/ 26 (C1 - cranial view; C2 - caudal view); D - left pelvis KPM 337/12, 28, 29, ventral view; E - left forearm KPM 337/ 31 and left hand KPM 337/1-7, 9-10,13-18, cranial view; F — first rib, cranial view (F1 - left rib KPM 337/8; F2 - right rib KPM 337/33); G — lumbar vertebra KPM 337/19 (G1 - cranial view; G2 — caudal view). Scale bar $=10 \mathrm{~cm}$. 


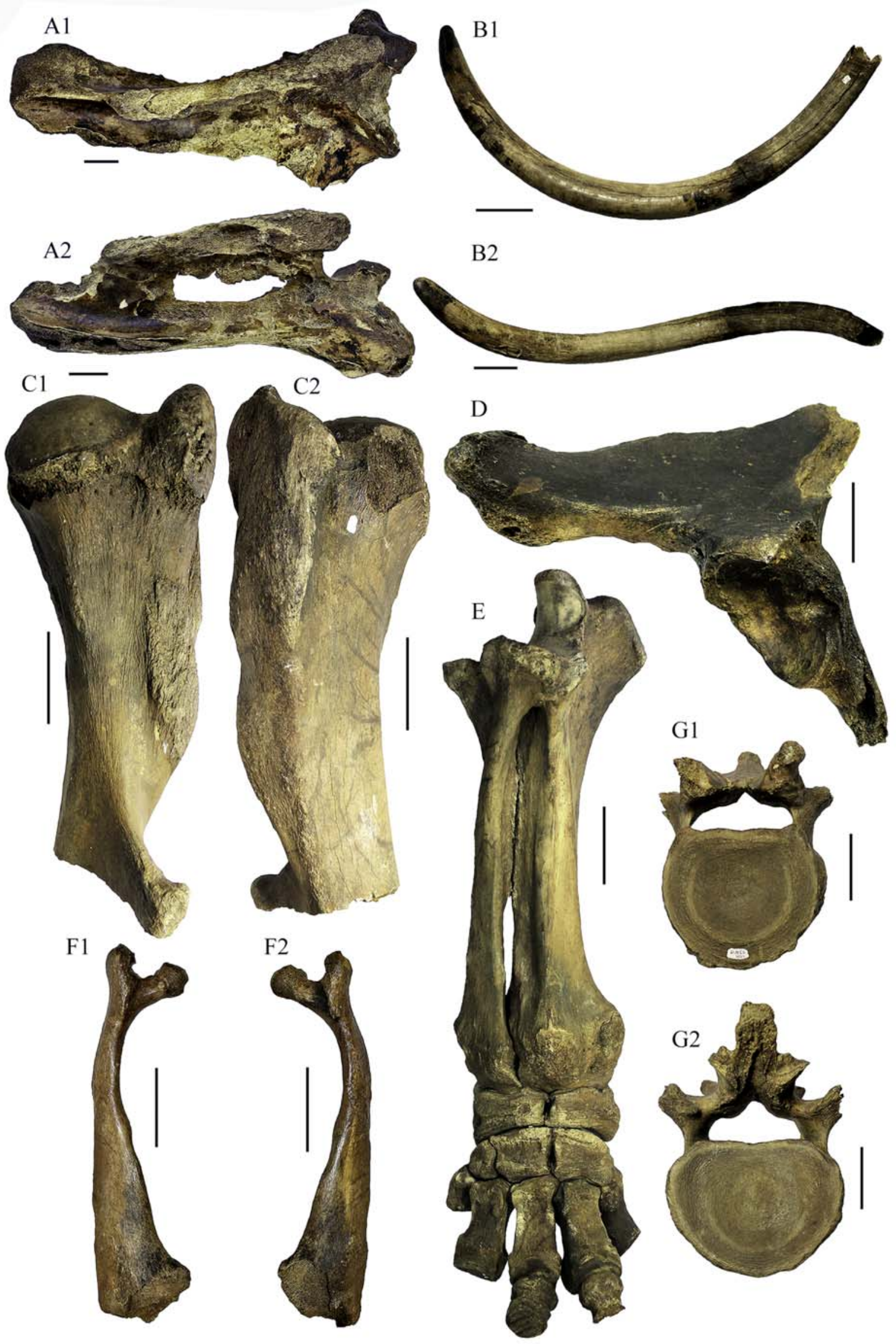


ramina of blood vessels, compared with the corresponding bone of the woolly mammoths from Kostenki, Kamskoe Ust'e and Berezovka. It is slightly smaller than that of the mammoths of Kostenki, Kamskoe Ust'e and the West Europe (S2).

Pisiform. - The left pisiform KPM $13475 / 2$ is complete (Fig. 7E; S2). The distal epiphysis is fused. The cuneiform facet is tongue-shaped and extends over roughly one third of the total length of the bone. The lateral surface of the bone is covered with a heavy tuberosity. This facet is very similar in the woolly mammoths of Kostenki and Rottweil. The lateral surface of the bone is covered with a heavy tuberosity, quite unlike certain $M$. primigenius specimens, such as those from Kostenki, Vetluga and Rottweil. The pisiforms are smaller than in comparable specimens (S2).

Trapezium. - The trapezium KPM 337/17 is a stout bone (Fig. 7E; S2). The scaphoideum facet is trapezoidal with a rounded border. The trapezium facet also is trapezoidal and has a marked proximo-palmar elongation. The facet for the Mc2 is small and tongueshaped. The slightly convex facet for the $\mathrm{Mcl}$ is of oval form with a straight lateral margin.

Trapezoid. - The left trapezoid KPM 337/1 is preserved (Fig. 7E; S2). The proximal and distal surfaces of this bone are triangular. The distal articular surface extends latero-caudally to form a facet for the capitate. The cranial and caudal surfaces of the bone are covered with a heavy tuberosity, in contrast to $M$. primigenius specimens such as those from Kostenki, Kamskoe Ust'e, Berezovka and Rottweil. The trapezoid of the Chernyanka mammoth is smaller than in the mammoths from Kostenki, Vetluga, Kamskoe Ust'e, Rottweil and Borna (S2).

Capitate. - The left capitate KPM 337/4 is complete (Fig. 7E). The proximal surface has almost parallel lateral and medial, and cranial and caudal borders. The capitate is palmar with a prominent tuberosity, unlike the Vetluga mammoth, but similar with the Rottweil and Borna mammoths. The capitate of the Chernyanka mammoth is smaller than in the mammoths of Kostenki, Vetluga, Kamskoe Ust'e, Rottweil and Borna (S2).

Hamatum. - The bone KPM 337/5 is complete, and as a whole is similar in shape to other known specimens of same ontogenetic age (Fig. 7E). There are no significant morphological differences with the hamatums of woolly mammoths from Kostenki, Vetluga, Berezovka, Rottweil or Borna. The hamatum dimensions are smaller than in comparable specimens (S2).

Metacarpals. - The left metacarpels Mc2-Mc5 KPM 337/6, 337/9, 337/10, 337/16 are preserved (Fig. $7 \mathrm{E})$ and are relatively slender. On each of them the distal epiphyses are fused. The cranial surfaces of the bones exhibit rugosity and differ by this criterion from the Kostenki and Vetluga woolly mammoths. The metacarpals of the Chernyanka mammoth are smaller than those in the mammoths of Vetluga, Kamskoe Ust'e, Rottweil and Borna (S2).

Phalanges. - Only the first phalanx of the third finger KPM 337/15 and the first phalanx of the fourth finger KPM 337/13 are preserved (Fig. 7E). The first phalanx of the third finger is complete, and is relatively massive and short (Fig. 5E). Its greatest length is 74 $\mathrm{mm}$. The proximal end is occupied by the rounded third metacarpal facet, which is slightly concave from the front backwards. The breadth and depth of the proximal end are 63 and $53 \mathrm{~mm}$, respectively. The oval facet for the second phalanx of the third finger is convex from its palmar to dorsal aspects. The breadth and the depth of the distal end are 52 and $39 \mathrm{~mm}$, respectively. The shaft is oval in cross-section. The proximal and distal epiphyses are fused. The first phalanx of the fourth finger has a missing part at the distal end. It is the most symmetrical phalanx. The fourth metacarpal facet is rounded and concave from its dorsal to palmar aspects. The breadth and the depth of the proximal end are 58 and $50 \mathrm{~mm}$, respectively. The proximal epiphysis is completely fused. In the first phalanx of the third and fourth fingers the proximal facets are inclined medially. These phalanxes are similar in breadth and depth at the proximal end.

Sesamoid bone. - The sesamoid bone KPM 337/ 14 has a more or less concave facet and is knob-shaped. It is $39 \mathrm{~mm}$ in length and $30 \mathrm{~mm}$ in width.

Pelvis. - The pelvis KPM 337/28 is represented by a fragment of the left acetabulum with the wing of the ilium (Fig. 7D; S2). The apophysis of the wing of the ilium is fused. The crest of the ilium and the dorsal surface of acetabulum are very tuberose, and distinguish the Chernyanka mammoth from the Vetluga, Khoma, Kamskoe Ust'e, and Berezovka mammoths.

\section{Discussion}

\section{Sex determination}

Vetluga mammoth. Morphological and morphometric features are the most helpful features in gender determination (Garutt, 1992; Averianov, 1996; Lister, 1996). The gender of the Vetluga mammoth was determined from several lines of evidence:

(i) Body size. - In woolly mammoths, for which the largest number of samples are available, males are on average about $20 \%$ larger in their linear dimensions than females (Averianov, 1996). The measurements from the present study, and those from published mate-

Fig. 8. Fusion of the ulna and the radius of M. primigenius and E. maximus. A — right ulna and radius of the Sanga-Yuryakh mammoth (female), ZIN 31738 (A1 - cranial view; A2 - medial view); B — right ulna and radius of the Taymyr mammoth (male), ZIN 2710 (B1 - cranial view; B2 - medial view); C - left ulna and radius of the E. maximus (female), ZIN 37337 (C1 - cranial view; C2 - medial view); D - right ulna and radius of the E. maximus (male), ZIN 30872 (D1 - cranial view; $\mathrm{D} 2$ - medial view). Scale bar $=10 \mathrm{~cm}$. 
Two mammoth skeletons from the Kirov Region

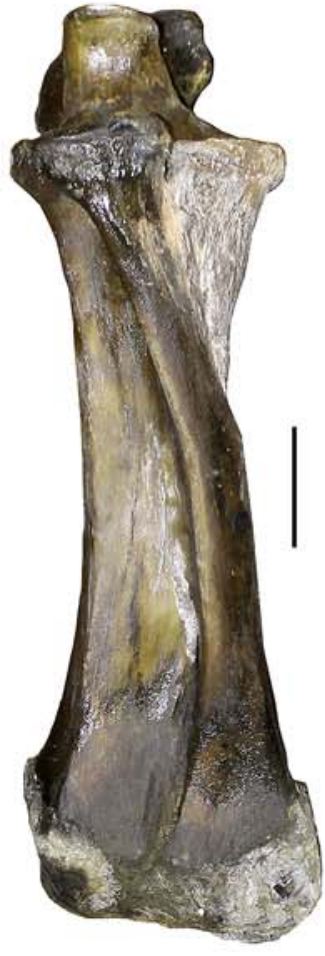

A1
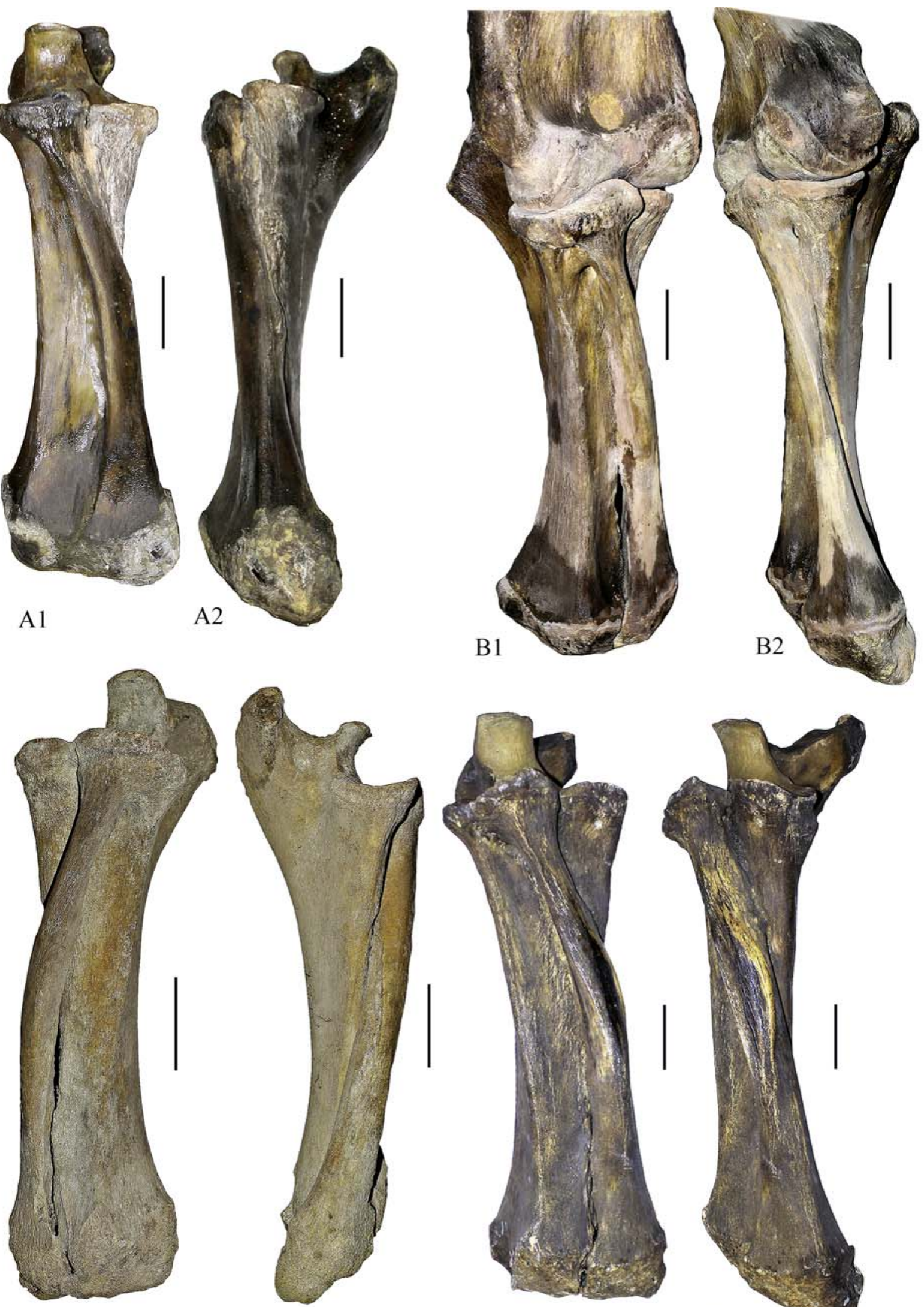

C1

C2

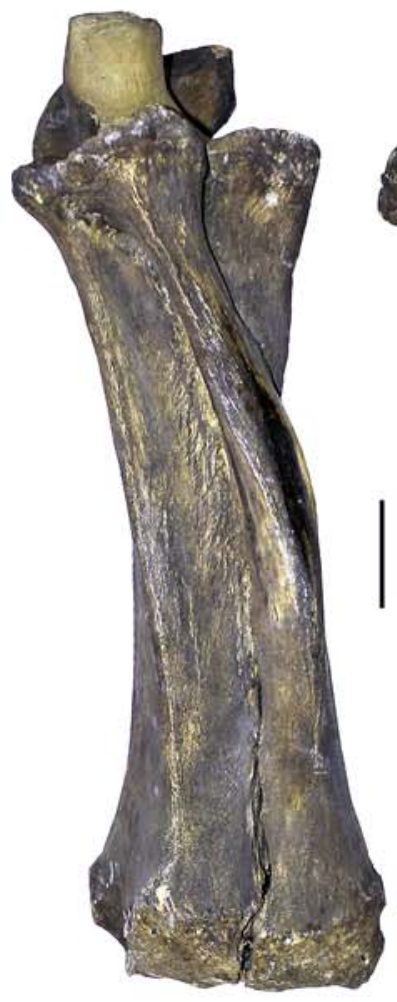

D1

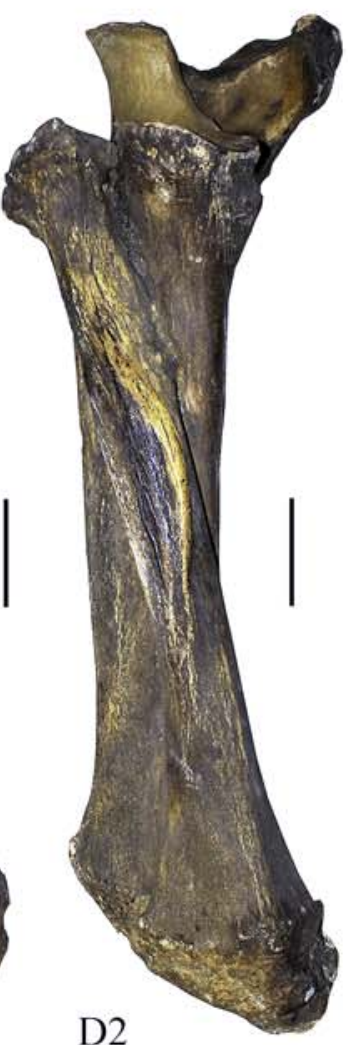


rials concerning known skeletons of $M$. primigenius (Zalenskiy, 1903; Felix, 1912; Siegfried, 1959; Koenigswald, 1989; Averianov, 1992; Garutt, 1992; Ziegler, 1994; Tikhonov, 1996; Ziegler, 2001; Lister, 2009; Petrova, 2009; Kirillova et al., 2012; Petrova et al., 2015) are given in Table $1(\mathrm{~S} 2)$. The morphometric comparison clearly indicates a similarity in size of the Vetluga mammoth with known male skeletons of $M$. primigenius from Russian Plain and Siberia (S2). The large size of the Vetluga individual argues in favour of a male.

(ii) Tusk size. - Tusk diameter in Mammuthus is strongly sexually dimorphic. In a large sample of adult M. primigenius tusks from Siberia, Vereshchagin and Tikhonov (1986) give a range of 47-90 $\mathrm{mm}$ in females, and $89-180 \mathrm{~mm}$ in males for tusk diameter at the base. The tusk data in the present sample strongly point to the male gender of the Vetluga mammoth, with a basal diameter of $160 \mathrm{~mm}$. Although it is incomplete, it exhibits a noticeable curvature that also suggest that this specimen is male.

(iii) Postcranial growth. - African elephant females have largely ceased growth in height by the age of 25, while males continue until around 45 years (Laws et al., 1975). Indian elephant females grow in height until the mid-twenties, and males until the mid-thirties (Sukumar et al., 1988). This implies that females complete their fusion sequence early than males (Haynes, 1991). The Vetluga individual was evidently incomplete in its fusion sequence (see below; S3). The unfused epiphyses in the proximal humerus, proximal femur, distal ulna, and the fused distal humerus and recently fused proximal ulna, at a dental age of $\mathrm{m} 2-\mathrm{m} 3$, is consistent with male gender, as a female would be expected to have completed growth and fused most epiphyses before this ontogenetic stage.

(iv) Pelvic form. - Lister (1996) showed that in $M$. primigenius, gender could be determined by the form of the pelvic girdle; in particular, in males, the pelvic aperture is relatively smaller, and the neck of the ilium relatively wider than in females, and the sexes can be separated by the ratio between these two measurements. The ratio between the transverse aperture width and the neck width in the Vetluga mammoth is 335/190 $=1.76$. In male $M$. primigenius $(\mathrm{n}=10)$, this ratio ranges from 1.92-2.38, with an outlier at 2.64, while in females $(n=4)$ the range is 2.63-2.81 (Lister, 1996). These indices unambiguously testify that the skeleton belonged to a male individual.

(v) Fusion of the ulna and the radius. - Our observations show that in adult mammoths the ulna and the radius are fused with each other (Fig. 7E; 8). In females this process begins at dental age $\mathrm{m} 2-\mathrm{m} 3$, when the distal epiphyses of these bones are unfused. In males, these bones are fused at a dental age of $\mathrm{m} 3$ by the time of or at the same time as the fusion of the distal epiphyses (Table 5). In addition, we studied several skeletons of Asian elephants, and observed that at the dental age $\mathrm{m} 2-\mathrm{m} 3$ the ulna and radius are fused with each other as in female and male mammoths (Table 6). In the male and the female of the Asian elephant, all epiphyses are completely fused at this dental age (Fig. 8C1, C2, D1, D2). The fusion of the ulna and the radius start earlier in the Asian elephant than in the woolly mammoth. The dental age of $\mathrm{m} 2-\mathrm{m} 3$ and the separate ulna strongly point to the male gender of the Vetluga mammoth (Fig. 5F1, F2).

Chernyanka mammoth. The gender of the Chernyanka mammoth was also determined also from several lines of evidence:

(i) Body size. - Morphometric comparisons showed the similarity in size of the Chernyanka mammoth with known female skeletons of $M$. primigenius from Western Europe and Siberia (S2).

(ii) Tusk size. - The mammoth from the Chernyanka river has a basal diameter of $57 \mathrm{~mm}$ and tusk is slightly involute. These data strongly point to the female gender.

(iii) Postcranial growth and fusion of the ulna and the radius. - The epiphyses of all long bones are fused. This specimen has an ulna and a radius, which are fused with each other. In Supplementary material (S3) showed the mammoth skeletons with their epiphyseal states simultaneously with presence of the M3 in middle and late wear stages. These features indicate that this individual was female or male. The basal diameter of the tusk, its slightly involute nature, and the small size of the bones indicate that the Chernyanka mammoth was female.

\section{Individual age}

Vetluga mammoth. There is a lot of literature concerning age determination of extant elephants by examining the stage of eruption and wear of the mandibular teeth (Laws, 1966; Sikes, 1967, 1971; Jachmann, 1988; Roth \& Shoshani, 1988). These data are usually applied to determine the age of mammoths from their dental remains.

The Vetluga mammoth mandible in the left half contains the second (m2) and the third (m3) molars, in the right half only the third (m3) molar is present. The second (m2) molar is in very late wear; the third (m3) molar is in middle wear. In Indian elephants, Elephas maximus Linnaeus, 1758, the second molar (m2) is in wear from 13 to 38 years (Roth \& Shoshani, 1988), while in African elephants, Loxodonta africana Cuvier F., 1827, it is in wear from 19 to 43 years according to some authors (Laws, 1966), and from 25 to 41 years according to others (Sikes, 1971). The third (m3) molar of Indian elephants is in wear from 37 to 67 years (Roth \& Shoshani, 1988), and in African elephants it is in wear from 31 to 60 years (Laws, 1966), or 30 years and later (Sikes, 1971). Applying these data, the estimated age of the Vetluga mammoth is 38-43 years.

In elephants (including mammoths), the long-bone epiphyses fuse over an extended period of time. This retarded epiphyseal fusion is the reason why in elephants the skeleton continues to grow for a long time in adult life. Different epiphyses of the skeleton fuse at 
different times in extant elephant species and also in mammoths (Roth, 1984; Lister, 1994, 1999). Accordingly, we used the state of epiphysis fusion for age determination and compared it with other M. primigenius skeletons. We have thus compiled a table like that of Lister (1999), including skeletons of M. primigenius discovered in the last 10-20 years (S3). We used data from skeletons that we studied ourselves and from articles with good quality images of the skeletons. In the Vetluga mammoth, most of the long-bone epiphyses (scapula, proximal humerus, distal ulna, proximal femur) are unfused, but the distal humerus is fused.

The Ahlen skeleton (Siegfried, 1959), in its mid30 s, was somewhat younger then the Vetluga mammoth, but has a similar state of epiphysis fusion (S3). The Khatanga individual is similar to the Vetluga mammoth in having the same state of epiphyses fusion and dental age, while the Achchyigyiy-Allaiha mammoth demonstrated a similar dental age, but with a fused proximal humerus. In the Kastykhtakh (Kirillova et al., 2012) and Oesh (Garutt, 1992) skeletons, which are aged 35-40 years, by contrast, most of the long bone epiphyses are fused (S3). This early fusion of epiphyses indicates a sexual dimorphism (Laws et al., 1975; Sukumar et al., 1988; Haynes, 1991; Lister, 1999; Maschenko, 2002). Lister (1999) used for his scheme only very young or very old females, because the skeletons in mid-life had not been discovered. New finds of complete skeletons of females have favoured the establishment of a scheme of bone fusion for the female mammoth, and allowed determination of the extent of the differences between the genders (Garutt, 1992; Kirillova et al., 2012). The data in Supplementary material (S3) show that females have a completely fused distal humerus, proximal and distal tibia and fibula, proximal ulna and distal femur at age 35-40 years. The proximal humerus and scapula at this age are in the process of fusing. The proximal femur is fused after 40 years. Possibly, the distal ulna and the radius are fused at age 40-50 years (S3). Males (from Ahlen, Khatanga, Vetluga), at the $\mathrm{m} 2-\mathrm{m} 3$ stage differ from females of the same dental age in their unfused proximal humerus and scapula (S3). Comparison the time of epiphysis fusion in females of $M$. primigenius with females of the two surviving elephant species shows a later period of epiphysis fusion in mammoths (Roth, 1984; Haynes, 1991).

In contrast, the male $M$. primigenius specimens from Kamskoe Ust'e (Averianov, 1992), Khoma (Petrova, 2009), Lyakhov Island (Tikhonov, 1996), and Berezovka (Zalenskiy, 1903) have a similar dental age and show unfused epiphyses (S3). This discrepancy between the dental age and the state of epiphysis fusion suggests that the definition (identification) of dental generation is not correct. Tikhonov (1997) has suggested that the Lyakhov mammoth is only $25-30$ years old, based on the supposition that its two teeth are M1 and M2. This dental allocation would better fit the unfused state of the epiphyses, but cannot be supported. In both the upper and lower jaws of the Lyakhov skull, the posterior tooth has 22 plates visible, with a few plates inside the alveolus at the posterior part of the jaws. This plate count is well beyond the range of M2 and clearly indicates the third molar. The last molar of the $M$. primigenius specimens from Kamskoe Ust'e, Khoma, and Berezovka, also have a large number of plates corresponding with the presence of the third molar (Zalenskiy, 1903; Averianov, 1992; Petrova, 2009). Now, the number of similar finds has increased and this group includes the mammoths from Kamskoe Ust'e and Khoma. In addition, a similar situation is observed in the Mammuthus trogontherii (Pohlig, 1855) from Chembakchino, in that at its dental age of approximately 30 years, all of the long bone epiphyses are unfused, except for the distal humerus, which is in the process of fusing (Kosintsev et al., 2004). Lister (1999), pointed out that the Berezovka and the Lyakhov mammoths have an anomalous unfused state and suggested that this may be the result of disease, malnourishment or hormonal malfunction.

During the period from the early to the late Pleistocene, members of the genus Mammuthus underwent adaptive changes increasing the number of tooth plates, compensating for increased wear due to climatic changes (aridisation). In this context, the contradiction between the dental age and the state of epiphysis fusion can be explained by faster wearing of the teeth caused by a specific composition of the diet or by "dustiness" caused by the inclusion of mineral particles in food. The skeletons of the Mokhov, Kozlowo and Taimyr mammoths may indicate this. These specimens with $\mathrm{m} 3$ in middle or late wear have incomplete fusion of the epiphyses (S3). In the Mohov mammoth, the proximal femur, distal ulna and radius are unfused; in the Kozlowo and Taimyr mammoths, the distal ulna and radius are in the process of fusing. We suppose that during the late Pleistocene, paleo landscape conditions appeared in different parts of the area, which increased wear on the teeth. This must be taken into account in diagnosing an individual's age and timing of epiphyses fusion. In addition, individual variability should be considered. For example, fusion of the distal femur before the proximal ulna, proximal and distal tibia and fibula is observed in the Khoma and Lyakhov mammoths (S3). The Kastykhtakh skeleton shows complete fusion of the proximal ulna and distal femur, ahead of the distal tibia and fibula (with a clear fusion line) (S3). Additionally, an unusual sequence of epiphysis fusion is found in the $M$. trogontherii specimen from West Runton (Lister \& Stuart, 2010). In this mammoth, most of the long-bone epiphyses (proximal and distal humerus, ulna, tibia and femur) are fused, but the scapula and distal radius are unfused (Lister \& Stuart, 2010). This situation is similar with the Vetluga mammoth in that the left distal femur is fused (the suture is fully obliterated), while the right distal femur is not (S3). Taking into account the variability of the epiphyseal fusion of long bones and the faster wearing of teeth, the individ- 
ual age of the Vetluga mammoth can be estimated as 35-43 years.

Chernyanka mammoth. The dental remains of the Chernyanka mammoth are unavailable, but the individual's age can be established by epiphysis fusion. In the Chernyanka mammoth the junctions between epiphyses and diaphyses of all preserved limb-bones are well fused, and the sutures are fully obliterated. The surfaces all bones show rugosity. These features indicate an old female, with an age estimated to be 50-60 years (S3).

\section{Taxonomic determination}

The taxonomic identity of the Vetluga and Chernyanka mammoths is indicated by morphological and morphometric features of their dental and postcranial anatomy. The relatively short, high horizontal ramus of the mandible, and the short rostrum of the Vetluga mammoth, are consistent with $M$. primigenius. The dimensions of the tusks and their curving form in the Vetluga and Chernyanka mammoths indicates $M$. primigeius (Fig. 3, 7B1, B2). The $\mathrm{m} 3$ parameters of the Vetluga mammoth are close to the mean value for Russian Plain and Siberia late Pleistocene M. primigenius specimens (Table 3 ). The comparison showed that the dimensions of the bones of the Vetluga and Chernyanka mammoths are consistent with the limits of variability within $M$. primigenius (S2). The mammoths from the Kirov region lived in the late Pleistocene. The age of the mammoth from Chernyanka River is estimated at $24280 \pm 670$ (GIN-15509) by radiocarbon dating, which corresponds to the Middle of Valdai interglacial.

These skeletons of the woolly mammoth $M$. primigenius appear to be among the most northerly specimens found on the Russian Plain.

\section{Conclusion}

The appearance of new finds of mammoth skeletons will make it possible to establish the approximate ontogenetic and sexual limits of the variability of this animal. But two general questions remain, which cannot be solved at present due to a shortage of material. As shown by our current results, all of the available mammoth material does not allow one to unequivocally solve the question about the determination of the relative age of individuals, since the relationship between epiphyseal fusion and tooth wear has not yet been established. Undoubtedly, determining the individual age of mammoths by teeth generation, we cannot account for differences in wear between different geographic and/or geological groups. On the other hand, we know that the "epiphyseal age" is influenced by the differences between males and females, but also by other factors. The wide variability in the processes of the growing epiphyses observed in our study (S3) cannot be explained solely by the physiological differences between males and females. Here, unaccounted factors may have a possible influence, such as pathology (sen$s u$ Leshchinskiy, 2012, 2017), or heterochrony.
ACKNOWLEDGEMENTS. We wish to thank to M. Sudovikov, E. Nalesnikova, I. Popova (KOMK) to provide access to Vetluga mammoth skeleton. The material for the study of the Chernyanka mammoth has been kindly provided by A. Toropov, T. Berestova, I. Shumov (KPM) and N. Patrushev (Local resident of the Shaleevshchina Village). The material for the comparison has been kindly provided by A.G. Mayorov (IEM), Dr. O. Shilovskiy (SGM), Dr. A.A. Sinitsyn (IHMC), Dr. N. Spasskaya, Dr. S. Kruskop and A. Tikhomirova (ZMMU). Our grateful to Dr. L. Voyta and Dr. M. Sablin (ZIN) for discussion and technical support of this work. We also thank Dr. V.V. Titov and Dr. S.V. Leshchinskiy for their valuable comments on the manuscript. The study was fulfilled within a framework of the Federal themes of the Theriology lab. of ZIN RAS no. AAAA-A17-117022810195-3 "Phylogeny, morphology and systematics of placental mammals", and was financially supported partly by the Russian Foundation for Basic Research, project no. 16-04-00294 À.

\section{References}

Averianov A.O. 1992. [Description of the mammoth remains from Kamskoe Ust'e] // Muraviev I.S. \& Solodukho M.G. (eds.). Volzhskaya fauna pleystotsenovykh mlekopitayuschikh $\mathrm{v}$ geologo-mineralogicheskom muzee Kazanskogo universiteta. Kazan: Kazan University Press. P.56-65 [in Russian].

Averianov A.O. 1994. [Kutomanov mammoth] // Trudy Zoologicheskogo Instituta RAN. Vol.256. P.111-135 [in Russian, with English summary].

Averianov A.O. 1996. Sexual dimorphism in the mammoth skull, teeth, and long bones // Shoshani J., Tassu P. (eds.). The Proboscidea. Oxford: Oxford University Press. P. 260-267.

Baigusheva V.S. \& Titov V.V., Timonina G.I. 2017. Skeleton of woolly mammoth from Nechereziy (Republic of Adygei, Russia) // Abstract Book of the VII-th International conference of mammoths and their relatives. 1723 September 2017. Taichung, Taiwan. NS2-1.

Berezin A.U., Petrova E.A. \& Berezina N.S. 2001. [The mammoth find (Mammuthus primigenius) from the neighbourhood of Khvadukasy village of the Krasnochetayskoe Prisur'e] // Nauchnye trudy gosudarstvennogo prirodnogo zapovednika "Prisurskiy". Vol.18. P.117-172 [in Russian].

Von den Driesch A. 1976. A guide to the measurement of animal bones from archaeological sites // Bulletin Peabody museum of archaeology and ethnology. Vol.1. P.1137.

Evans H.E. 1993. Miller's anatomy of the dog. Philadelphia: W.B. Saunders Company. 1113 p.

Felix J. 1912. Das Mammuth von Borna // Veröffentl. städt. Museum Völkerkde. Bd.4. S.1-52.

Garutt V.E. 1992. [The skeleton of mammoth Mammuthus primigenius (Blumenbach, 1799) from the neighbourhood of Kozlovo village of Chermezsk area Perm Region] // Muraviev I.S. \& Solodukho M.G. (eds.). Volzhskaya fauna pleystotsenovykh mlekopitayuschikh $\mathrm{v}$ geologo-mineralogicheskom muzee Kazanskogo universiteta. Kazan: Kazan University Press. P.31-54 [in Russian]. 
Garutt V.E. \& Foronova I.V. 1976. [Research of teeth of extinct elephants. Methodological recommendations] Novosibirsk: Institute of Geology and Geophysics, Siberian Branch AN SSSR. 36 p. [in Russian]

Haynes G. 1991. Mammoths, mastodonts and elephants. Biology, behavior, and the fossil record. Cambridge: Cambridge University Press. $413 \mathrm{p}$.

Ismagilova G.M. 1992. [The main finds of the large mammals from Bashkir Predural and their stratigraphic significance] // Kamaletdinov M A. \& Suleymanova F.I. (eds.). Flora i fauna Predural'ya i nekotorye aspekty magnitostratigrafii. Ufa: BNC UrO. 132 p. [in Russian]

Jachmann H. 1988. Estimating age in African elephants: a revision of Law's molar evaluation technique // African Journal of Ecology. Vol.26. P.51-56.

Khromov A.A., Arkhangelskii M.S. \& Ivanova A.V. 2001. [Large quaternary mammals from Middle and Lower Volga Region] Dubna: International University of Nature, Society and Man "Dubna". 254 p. [in Russian]

Kirillova I.V., Shidlovskiy F.K. \& Titov V.V. 2012. Kastykhtakh mammoth from Taimyr (Russia) // Quaternary International. Vol.276-277. P.269-277.

Koenigswald W. v. 1989. Das Mammut von Polch bei Mayen (Eifel) // Eiszeitalter und Gegenwart. Bd.39. S.87-97.

Kosintsev P.A., Bobkovskaya N.E., Borodin A.V., Zinoviev E.A., Nekrasov A.I. \& Trofimova S.S. 2004. [Trogontherian Elephant of the Lower Irtysh]. Ekaterinbourg: Volot Press. 260 p. [in Russian]

Laws R.M. 1966. Age criteria for the African elephant Loxodonta africana // East African Wildlife Journal. Vol.4. P.1-37.

Laws R.M., Parker I.S.C. \& Johnstone R.C.C. 1975. Elephants and habitats in North Bunyoro, Uganda. Oxford: Oxford University Press. 315 p.

Leshchinskiy S.V. 2012. Paleoecological investigation of mammoth remains from the Kraków Spadzista Street (B) site // Quaternary International. Vol.276-277. P.155169.

Leshchinskiy S.V. 2017. Strong evidence for dietary mineral imbalance as the cause of osteodystrophy in Late Glacial woolly mammoths at the Berelyokh site (Northern Yakutia, Russia) // Quaternary International. Vol.445. P.146170.

Lister A.M. 1996. Sexual dimorphism in the mammoth pelvis: an aid to gender determination // Shoshani J. \& Tassy P. (eds.). The Proboscidea: Trends in Evolution and Paleoecology. Oxford: Oxford University Press. P. 254259.

Lister A.M. 1999. Epiphyseal fusion and postcranial age determination in the woolly mammoth Mammuthus primigenius // Deinsea. Vol.6. P.79-87.

Lister A.M. 2009. Late-glacial mammoth skeletons (Mammuthus primigenius) from Condover (Shropshire, UK): anatomy, pathology, taphonomy and chronological significance // Geological Journal. Vol.44. P.447-479.

Lister A.M. \& Stuart A.J. 2010. The West Runton mammoth (Mammuthus trogontherii) and its evolutionary significance // Quaternary International. Vol.228. P.180-209.

Lister A.M. 1994. Skeletal associations and bone maturation in the Hot Springs mammoths. // Agenbroad L.D. \& Mead J.I. (eds.). The Hot Springs Mammoth Site: A Decade of Field and Laboratory Research in Paleontology, Geology and Paleoecology. Hot Springs, SD: Mammoth Site Inc. P.253-268.
Maschenko E.N. 1992. [Structure of a mammoth herd from the Sevsk Late Pleistocene locality (Russia, Bryansk Region)] // Trudy Zoologicheskogo Instituta RAN. Vol. 246. P.41-59 [in Russian, with English summary].

Maschenko E.N. 2002. Individual development, biology and evolution of the wooly mammoth // Cranium. Vol.19. P.4-114.

Petrova E.A. 2009. [Mammoth (Mammuthus primigenius) from the Late Pleistocene of Chuvashiya, European Russia] // Proceedings of the Zoological Institute RAS. Vol.313. No.1. P.58-67 [in Russian, with English summary].

Petrova E.A., Burova N.D. \& SinitsynA.A. 2015. [The skeleton of mammoth (Mammuthus primigenius) from the Upper Paleolithic site Kostenki 14 (Markina Gora), European Russia] // Proceedings of the Zoological Institute RAS. Vol.319. No.3. P. 378-400 [in Russian, with English summary].

Roth V.L. 1984. How elephant grow: Heterochrony and calibration of developmental stages in some living and fossil species // Journal of Vertebrate Paleontology. Vol.4. P.126-145.

Roth V.L. \& Shoshani J. 1988. Dental identification and age determination in Elephas maximus // Journal of Zoology. Vol.214. P.567-588.

Siegfried P. 1959. Das Mammut von Ahlen Mammontheus primigenius (Blumenb.) // Paläontologische Zeitschrift. Bd.33. H.3. S.172-184.

Sikes S.K. 1966. The African elephant, Loxodonta africana: A field method for the estimation of age // Journal of Zoology. Vol.150. P.279-295.

Sikes S.K. 1971. The natural history of African elephant. London: American Elsevier Publishing Company. 397 p.

Sukumar R., Joshi N.V. \& Krishnamurthy V. 1988. Growth in the Asian elephant // Proceedings of the Indian Academy of Science (Animal Science). Vol.97. P.561-571.

Tikhonov A.N. 1996. [Wooly mammoth Mammuthus primigenius (Elephantidae, Proboscidae) from Bolshoy Lyakhovsky Island, East Siberia] // Trudy Zoologicheskogo Instituta RAN. Vol.270. P.167-185 [in Russian, with English summary].

Vereshchagin N.K. 1977. [Berelekh "cemetery" of mammothes] // Trudy Zoologicheskogo Instituta AN SSSR. Vol.72. P.5-49 [in Russian].

Vereshchagin N.K. 1979. [Why did mammoths die out?] Leningrad: Nauka. 200 p. [In Russian]

Vereshchagin N.K., Tikhonov A.N. 1986. [A Study on Mammoth Tusks] // Trudy Zoologicheskogo Instituta AN SSSR. Vol.149. P.3-14 [in Russian].

Zalenskiy V.V. 1903. [Osteological and odontographic studies on the mammoth (Elephas primigenius Blum.) and elephants (El. indicus L. and El. africanus Blum)] // Scientific results of the expedition sent by the Imperial Academy of Science for the excavation of mammoth found on Berezovka River. Vol.1. P.1-124 [in Russian].

Ziegler R. 1994. Das Mammut (Mammuthus primigenius Blumenbach) von Siegsdorf bei Traunstein (Bayern) und seine Begleitfauna // Münchner Geowissenschaftliche Abhandlungen Reihe A. Bd.26. S.49-80.

Ziegler R. 2001. An extraordinary small mammoth (Mammuthus primigenius) from SW Germany // Geologie und Paläontologie. Stuttgarter Beiträge zur Naturkunde. Series B. Vol.300. P.1-41. 


\begin{tabular}{|c|c|c|c|c|c|c|c|c|c|c|c|c|c|c|c|c|c|c|c|c|c|c|}
\hline 递 & $\begin{array}{l}n \\
0 \\
0 \\
\vdots \\
\vdots \\
0 \\
0 \\
\tilde{J} \\
0 \\
0 \\
0 \\
0 \\
0\end{array}$ & 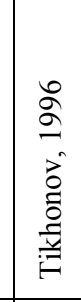 & 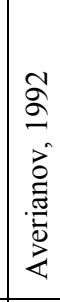 & 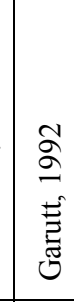 & 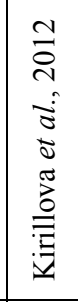 & 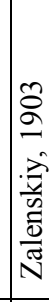 & 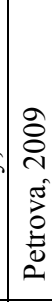 & & 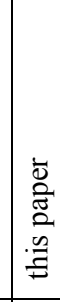 & & 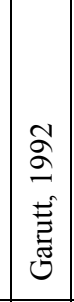 & 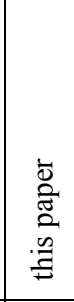 & 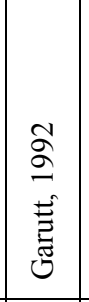 & 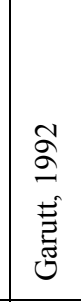 & 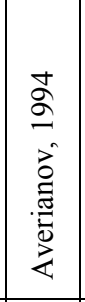 & 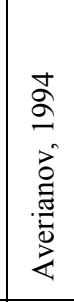 & 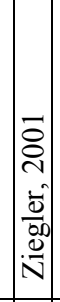 & 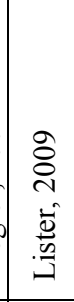 & . & 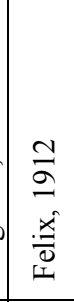 & & 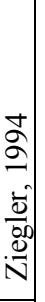 \\
\hline 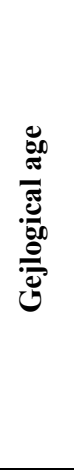 & 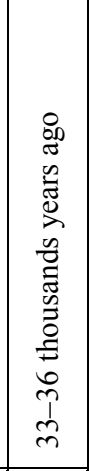 & 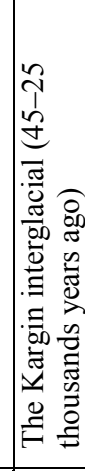 & & & 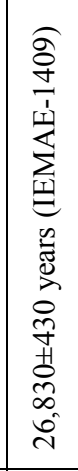 & 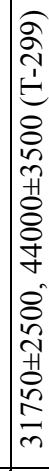 & 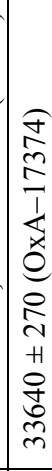 & 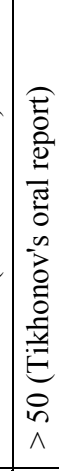 & & 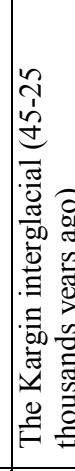 & 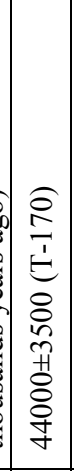 & 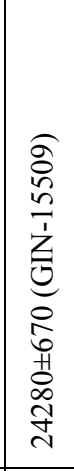 & & 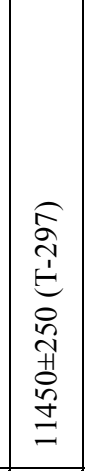 & 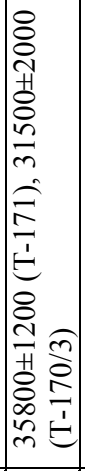 & 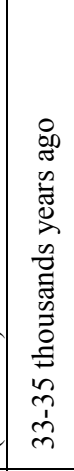 & 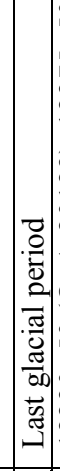 & 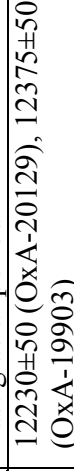 & 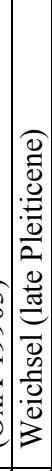 & 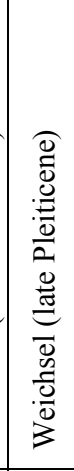 & 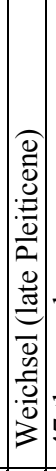 & 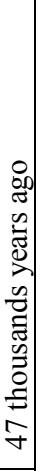 \\
\hline 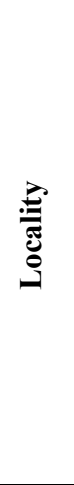 & 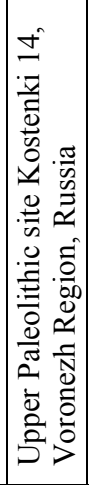 & 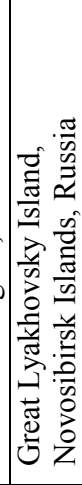 & 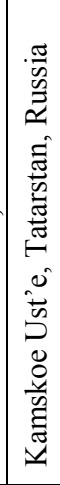 & 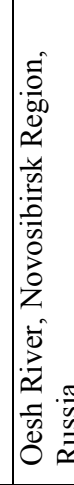 & 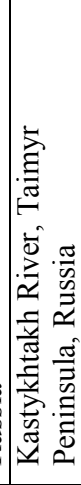 & 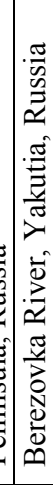 & 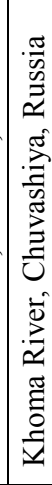 & $\mid$ & 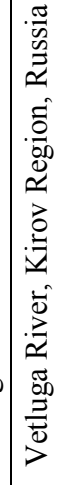 & 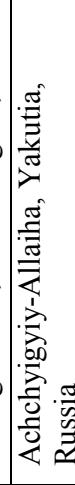 & 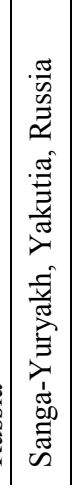 & 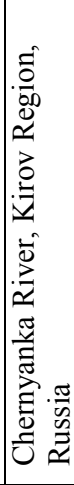 & 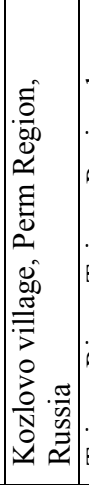 & 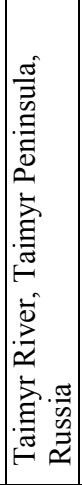 & 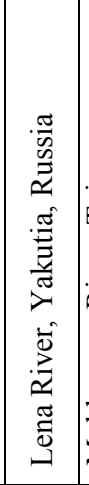 & 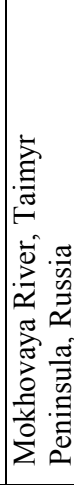 & 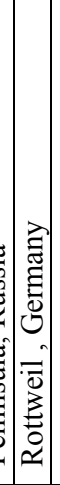 & 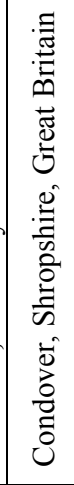 & 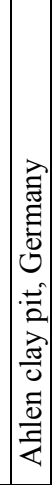 & 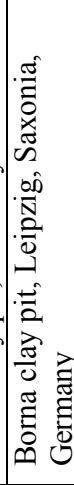 & 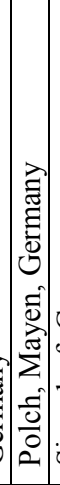 & 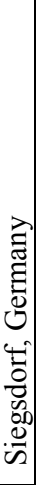 \\
\hline$\stackrel{\vec{b}}{\dot{\omega}}$ & 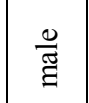 & 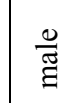 & 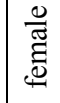 & 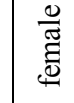 & 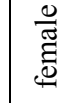 & $\mid \frac{0}{\tilde{\Xi}}$ & $\frac{0}{\widetilde{\Xi}}$ & 苞 & 㫕 & 峁 & 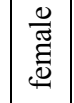 & 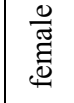 & 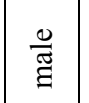 & 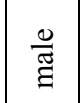 & 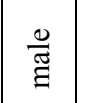 & 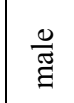 & & 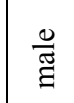 & $\mid \begin{array}{c}\frac{0}{\tilde{\Xi}} \\
\stackrel{\Xi}{\Xi}\end{array}$ & $\frac{\stackrel{\circlearrowright}{\widetilde{\Xi}}}{\stackrel{\Xi}{\Xi}}$ & & $\frac{\stackrel{0}{\overparen{m}}}{\stackrel{\Xi}{\Xi}}$ \\
\hline 焉 & $\frac{\sum_{1}^{I}}{\sum}$ & 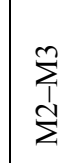 & $\mid \begin{array}{l}\sum_{1}^{n} \\
\tilde{\Sigma} \\
\Sigma\end{array}$ & $\sum_{i=1}^{n}$ & 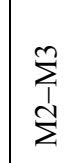 & $\mid \begin{array}{l}\sum_{1}^{m} \\
\tilde{\Sigma} \\
\Sigma\end{array}$ & $\begin{array}{l}\text { ڤ్ } \\
\text { ปี }\end{array}$ & 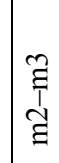 & $\begin{array}{l}\tilde{\Xi} \\
\tilde{Z} \\
\Xi\end{array}$ & 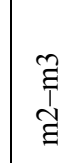 & $\sum^{m}$ & & $\sum^{n}$ & $\sum^{m}$ & $\sum_{\Sigma}^{m}$ & $\sum$ & $\mid \begin{array}{l}0 \\
\vdots \\
0 \\
\vdots \\
\vdots \\
\lambda \\
\wedge\end{array}$ & $\begin{array}{l}\widetilde{\Xi} \\
\overparen{\Xi}\end{array}$ & $\mid \begin{array}{c}\tilde{\Xi} \\
\bar{I} \\
\mathfrak{Z} \\
\mid\end{array}$ & $\sum$ & & 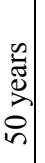 \\
\hline 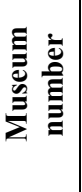 & 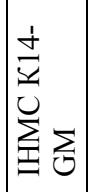 & 1 & 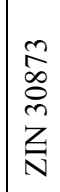 & 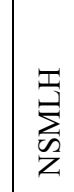 & 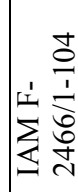 & 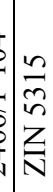 & 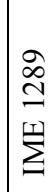 & $\begin{array}{l}\text { సे } \\
\infty \\
m \\
z \\
\bar{N}\end{array}$ & 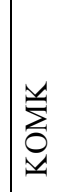 & 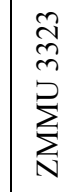 & 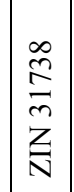 & $\sum_{\tilde{\Xi}}$ & 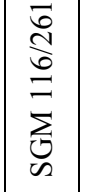 & $\begin{array}{l}\stackrel{\circ}{N} \\
\underset{N}{N}\end{array}$ & $\begin{array}{l}\bar{a} \\
\frac{a}{2} \\
z \\
N\end{array}$ & 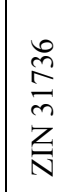 & 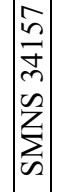 & $\begin{array}{l}0 \\
\bigcup \\
ٍ \\
ٍ\end{array}$ & 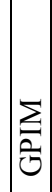 & 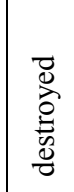 & & $\sum_{z}^{n}$ \\
\hline 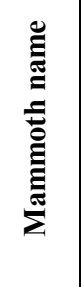 & 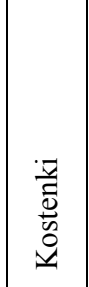 & 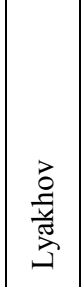 & 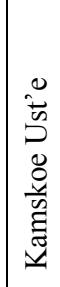 & 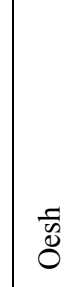 & 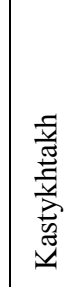 & 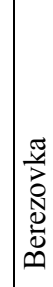 & $\begin{array}{l}\tilde{\Xi} \\
\tilde{0} \\
\tilde{\nabla}\end{array}$ & 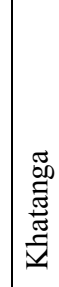 & 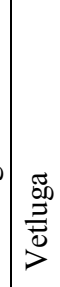 & 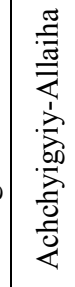 & 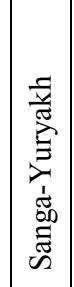 & 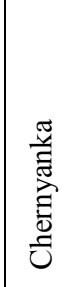 & \begin{tabular}{l}
$\frac{0}{3}$ \\
$\frac{0}{N}$ \\
\multirow{2}{4}{}
\end{tabular} & 镸 & 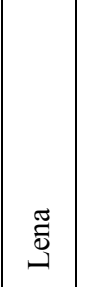 & 总 & 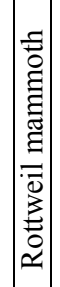 & $\begin{array}{l}\overrightarrow{0} \\
\overline{0} \\
\bar{z} \\
\overline{0}\end{array}$ & $\mid \frac{\bar{v}}{\frac{\pi}{\mathbb{d}}}$ & 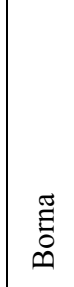 & & 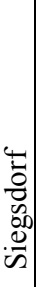 \\
\hline$\Xi$ & - & $N$ & $m$ & $\nabla$ & in & 0 & $\pi$ & $\infty$ & $a$ & 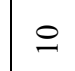 & $=$ & $\simeq$ & $\stackrel{m}{-}$ & $\Xi$ & $\because$ & $\stackrel{\varrho}{-}$ & $\Xi$ & $\stackrel{\infty}{-}$ & 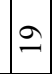 & ¿ి & v) & \\
\hline
\end{tabular}




\begin{tabular}{|c|c|c|c|c|c|c|c|c|c|c|c|c|}
\hline 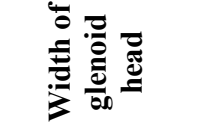 & 1 & 8 & 1 & $\frac{n}{n}$ & $\frac{n}{i}$ & 1 & $\stackrel{\infty}{\vec{r}}$ & $\hat{n}$ & $\because$ & t & 8 & 6 \\
\hline 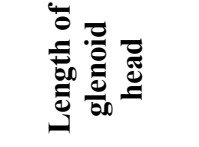 & 1 & $\nabla$ & 1 & \pm & $\infty$ & 1 & $\begin{array}{l}\infty \\
\dot{1} \\
\infty\end{array} \mid$ & $\ddot{0}$ & 2 & $\infty$ & $\tilde{\infty}$ & $F$ \\
\hline 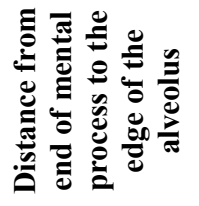 & $\stackrel{?}{\sim}$ & 1 & $\stackrel{\check{c}}{\tilde{\nu}}$ & 1 & छे & $\overrightarrow{\mathbb{N}}$ & $\stackrel{\sim}{\beth}$ & $\hat{n}$ & $\underline{\sigma}$ & $\mid \begin{array}{l}\infty \\
\infty \\
-1\end{array}$ & $\stackrel{\infty}{\infty}$ & సे \\
\hline 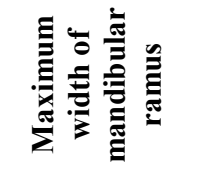 & $\stackrel{\text { qu }}{\sim}$ & 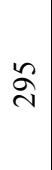 & 1 & $\stackrel{\infty}{\sim}$ & $\begin{array}{l}\infty \\
\stackrel{0}{N}\end{array}$ & $\stackrel{\oslash}{\curvearrowright}$ & 1 & $\stackrel{\infty}{2}$ & $\overrightarrow{\underset{\sim}{\sim}}$ & $\underset{\sim}{\mathbb{N}}$ & ñ & iे \\
\hline 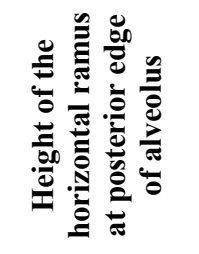 & 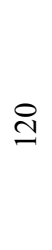 & $\stackrel{n}{n}$ & $\hat{m}$ & $\stackrel{\infty}{=}$ & I & છે & $\stackrel{\infty}{ \pm}$ & $\cong$ & 告 & $\begin{array}{l}m \\
m\end{array}$ & $\stackrel{\sim}{m}$ & 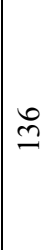 \\
\hline 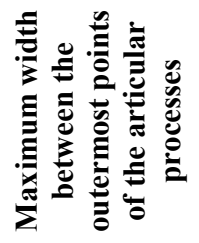 & $\stackrel{\overbrace{}}{\Im}$ & $\begin{array}{l}n \\
q \\
q\end{array}$ & 1 & $\overrightarrow{7}$ & $\frac{n}{\gamma}$ & $\frac{n}{\sigma}$ & 1 & $\vec{F}$ & 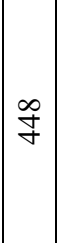 & $\mid \begin{array}{l} \pm \\
\sigma\end{array}$ & $\stackrel{P}{+}$ & F \\
\hline 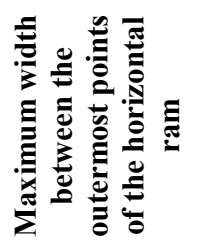 & 1 & $\stackrel{\sim}{\mathcal{f}}$ & 1 & $\begin{array}{l}\dddot{y} \\
y\end{array}$ & $\frac{ \pm}{n}$ & 1 & $\begin{array}{l}\infty \\
\dot{\infty} \\
+\end{array}$ & $\begin{array}{l}8 \\
⿱ 亠 乂 \\
q\end{array}$ & $\vec{n}$ & $\tilde{\tilde{n}}$ & $\mid \begin{array}{c}0 \\
\stackrel{\infty}{\sigma}\end{array}$ & $\stackrel{?}{f}$ \\
\hline 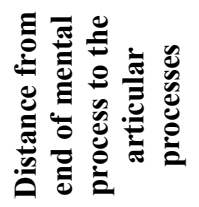 & 8 & $\frac{8}{6}$ & 1 & 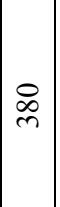 & $\frac{2}{6}$ & 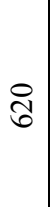 & 1 & 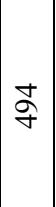 & $\widehat{\widehat{\sigma}}$ & $\begin{array}{l}\infty \\
\mathbb{J}\end{array}$ & $\left|\begin{array}{l}\infty \\
\infty \\
\infty\end{array}\right|$ & $:$ \\
\hline 童。 & 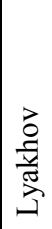 & 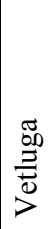 & 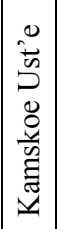 & 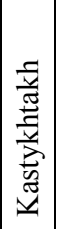 & 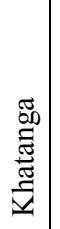 & 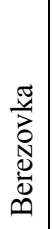 & 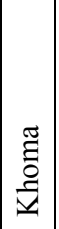 & 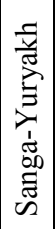 & 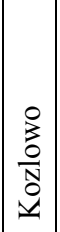 & 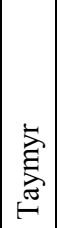 & $\mid \begin{array}{c}z \\
0 \\
\frac{\vec{t}}{0} \\
\dot{0} \\
\Sigma\end{array}$ & 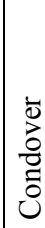 \\
\hline$\Xi$ & - & $v$ & m & $\sigma$ & in & 0 & r & $\infty$ & $a$ & 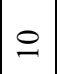 & $=$ & $\simeq$ \\
\hline
\end{tabular}




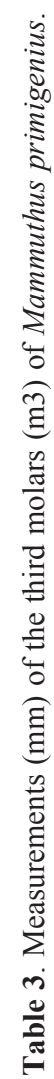

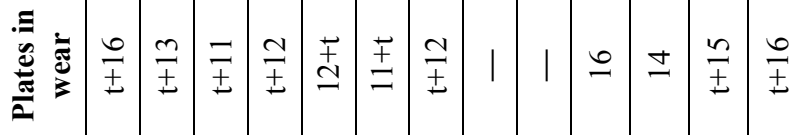

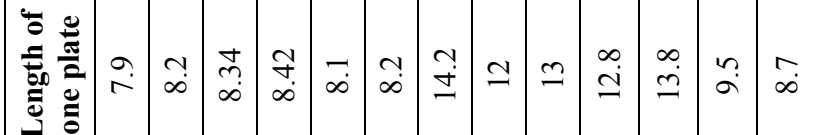

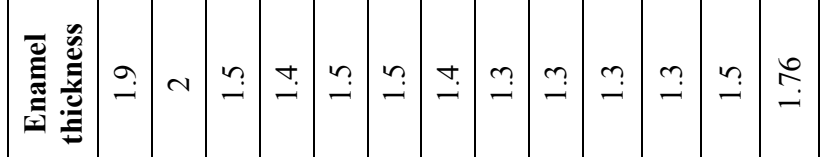

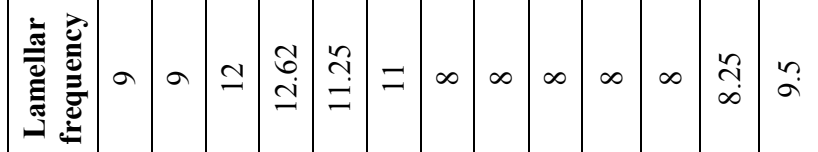

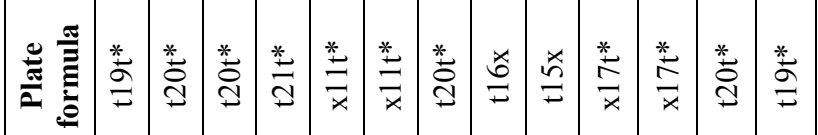

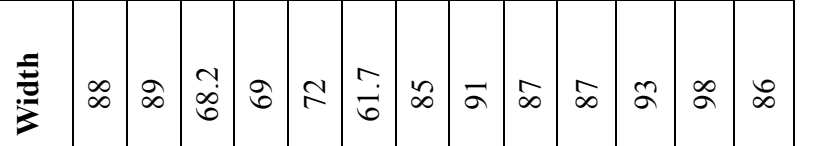

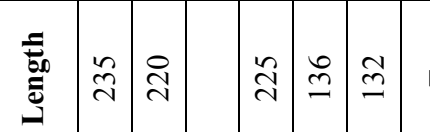

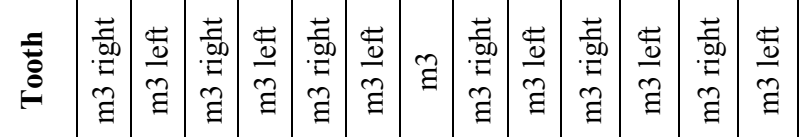

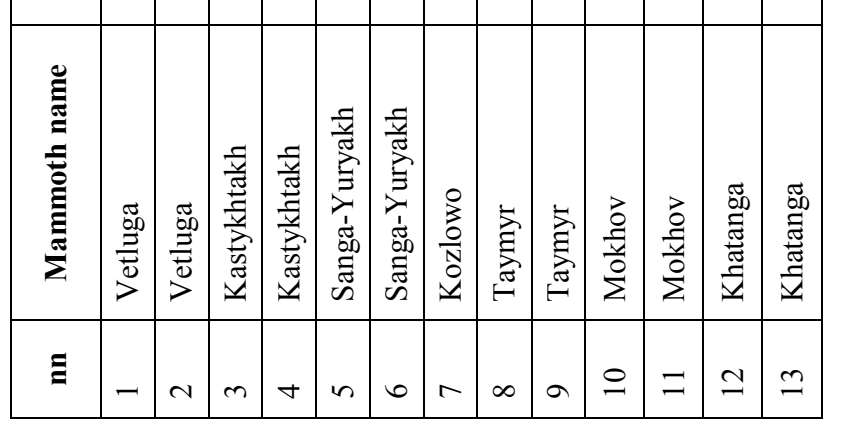

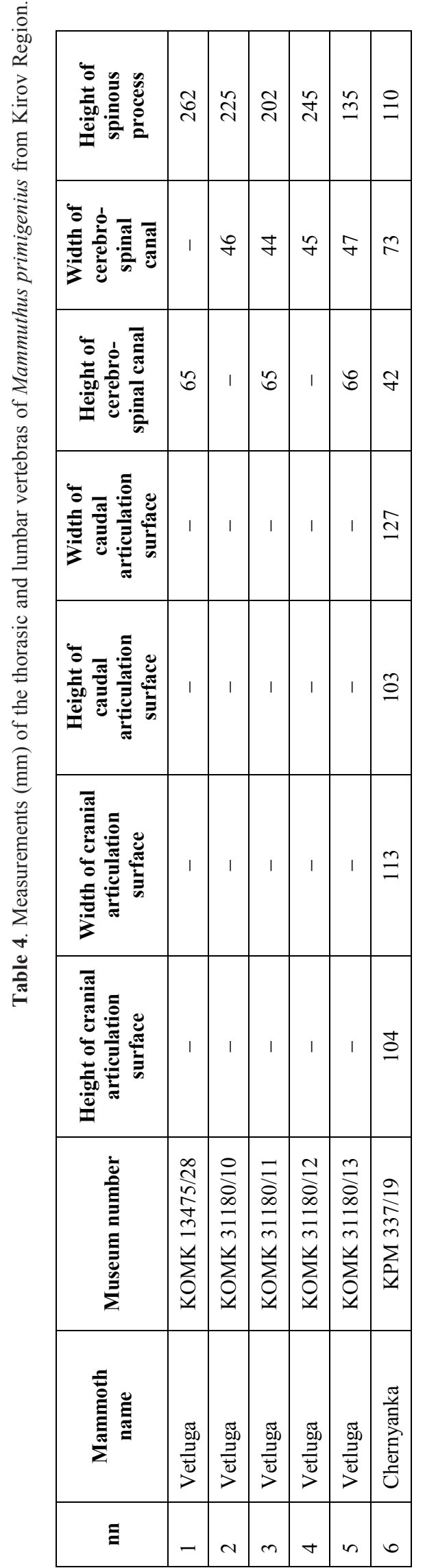


Table 5. The states of the ulna and radius fusion in Mammuthus primigenius.

\begin{tabular}{|c|c|c|c|c|c|c|}
\hline $\mathrm{nn}$ & Mammoth name & Sex & Dental stage of wear & Ulna and radius & Distal ulna & Distal radius \\
\hline 1 & Kostenki & male & $\mathrm{M} 11-\mathrm{M} 2 \mathrm{~m}$ & unfused & unfused & unfused \\
\hline 2 & Kamskoe Ust'e & female & M2m-1-M3e-m; m2m-m3e & unfused & unfused & unfused \\
\hline 3 & Ahlen & male & $\mathrm{m} 2 \mathrm{~m}-1-\mathrm{m} 3 \mathrm{e}$ & unfused & unfused & unfused \\
\hline 4 & Kastykhtakh & female & $\mathrm{M} 2 \mathrm{~m}-\mathrm{M} 3 \mathrm{~m} ; \mathrm{m} 2 \mathrm{~m}-\mathrm{l}-\mathrm{m} 3 \mathrm{~m}$ & $\begin{array}{l}\text { in the process of } \\
\text { fusing }\end{array}$ & unfused & unfused \\
\hline 5 & Lyakhov & male & $\mathrm{M} 2 \mathrm{~m}-1-\mathrm{M} 3 \mathrm{~m} ; \mathrm{m} 2 \mathrm{l}-\mathrm{m} 3 \mathrm{~m}$ & unfused & unfused & unfused \\
\hline 6 & Oesh & female & $\mathrm{M} 2 \mathrm{l}-\mathrm{M} 3 \mathrm{~m} ; \mathrm{m} 2 \mathrm{l}-\mathrm{m} 3 \mathrm{~m}$ & fused & unfused & unfused \\
\hline 7 & Berezovka & male & $\mathrm{M} 21-\mathrm{M} 3 \mathrm{~m} ; \mathrm{m} 21-\mathrm{m} 3 \mathrm{~m}$ & unfused & unfused & unfused \\
\hline 8 & Khatanga & male & $\mathrm{M} 3 \mathrm{~m} ; \mathrm{m} 21-\mathrm{m} 3 \mathrm{~m}$ & unfused & unfused & unfused \\
\hline 9 & Vetluga & male & $\mathrm{m} 2 \mathrm{vl}-\mathrm{m} 3 \mathrm{~m}$ & unfused & unfused & unfused \\
\hline 10 & $\begin{array}{l}\text { Achchyigyiy- } \\
\text { Allaiha } \\
\text { mammoth }\end{array}$ & male & $\mathrm{m} 2 \mathrm{vl}-\mathrm{m} 3 \mathrm{~m}$ & unfused & unfused & unfused \\
\hline 11 & Kozlowo & male & $\mathrm{M} 3 \mathrm{~m} ; \mathrm{m} 3 \mathrm{~m}$ & unfused & unfused & unfused \\
\hline 12 & Mokhov & male & $\mathrm{M} 3 \mathrm{~m} ; \mathrm{m} 3 \mathrm{~m}$ & unfused & unfused & unfused \\
\hline 13 & Taymyr & male & M3m-1; m3m-1 & fused & fused & fused \\
\hline 14 & Lena & male & $\mathrm{M} 3 \mathrm{~m} ; \mathrm{m} 3 \mathrm{~m}$ & fused & fused & fused \\
\hline 15 & Sanga-Yuryakh & female & M3m-1; m3m-1 & fused & fused & fused \\
\hline 16 & Chernyanka & female & - & fused & fused & fused \\
\hline
\end{tabular}

Notes: Tooth generation (in upper and lower jaws) and state of wear: e — early; $\mathrm{m}$ — middle; 1 — late; v — very.

Table 6. The states of the ulna and radius fusion in Elephas maximus.

\begin{tabular}{|l|l|c|l|c|c|c|}
\hline nn & Museum number & Sex & Dental stage of wear & $\begin{array}{c}\text { Ulna and } \\
\text { radius }\end{array}$ & Distal ulna & Distal radius \\
\hline 1 & ZIN 37337 & female & $\mathrm{m} 2 \mathrm{~m}$ & fused & fused & fused \\
\hline 2 & ZIN 38090 & female & $\mathrm{m} 2 \mathrm{~m}-1-\mathrm{m} 3 \mathrm{e}$ & fused & fused & fused \\
\hline 3 & ZIN 30871 & female & $\mathrm{m} 3 \mathrm{~m}-1$ & fused & fused & fused \\
\hline 4 & ZIN 30872 & male & $\mathrm{m} 2 \mathrm{~m}-1-\mathrm{m} 3 \mathrm{e}$ & fused & fused & fused \\
\hline 5 & ZMMU 152807 & male & $\mathrm{m} 3 \mathrm{e}-\mathrm{m}$ & fused & fused & fused \\
\hline 6 & ZMMU 182211 & male & $\mathrm{m} 3 \mathrm{~m}-1$ & fused & fused & fused \\
\hline
\end{tabular}

Notes: Tooth generation (in upper and lower jaws) and state of wear: e — early; $m$ - middle; 1 - late; v — very. 